\title{
Dietary plant proteins and vegetable oil blends increase adiposity and plasma lipids in Atlantic salmon (Salmo salar L.)
}

\author{
Bente E. Torstensen $^{1 *}$, Marit Espe ${ }^{1}$, Ingunn Stubhaug ${ }^{1,2}$ and $\varnothing$ yvind Lie $^{1}$ \\ ${ }^{1}$ National Institute of Nutrition and Seafood Research (NIFES), PO Box 2029, Strandgt 229, 5817 Bergen, Norway \\ ${ }^{2}$ Skretting Aquaculture Research Centre, Stavanger, Norway \\ (Received 20 September 2010 - Revised 8 December 2010 - Accepted 26 January 2011 - First published online 3 May 2011)
}

\section{Abstract}

In order to study whether lipid metabolism may be affected by maximum replacement of dietary fish oil and fish meal with vegetable oils (VO) and plant proteins (PP), Atlantic salmon (Salmo salar L.) smolts were fed a control diet containing fish oil and fish meal or one of three plant-based diets through the seawater production phase for 12 months. Diets were formulated to meet all known nutrient requirements. The whole-body lipid storage pattern was measured after 12 months, as well as post-absorptive plasma, VLDL and liver TAG. To further understand the effects on lipid metabolism, expression of genes encoding for proteins involved in VLDL assembly (apoB100), fatty acid uptake (FATP1, cd36, LPL and FABP3, FABP10 and FABP11) were measured in liver and visceral adipose tissue. Maximum dietary VO and PP increased visceral lipid stores, liver TAG, and plasma VLDL and TAG concentrations. Increased plasma TAG correlated with an increased expression of apoB100, indicating increased VLDL assembly in the liver of fish fed the high-plant protein- and VO-based diet. Atlantic salmon fed intermediate replacement levels of VO or PP did not have increased body fat or visceral mass. Overall, the present results demonstrate an interaction between dietary lipids and protein on lipid metabolism, increasing overall adiposity and TAG in the body when fish meal and fish oil are replaced concomitantly at maximised levels of VO and PP.

Key words: Vegetable oil: Plant protein: Fish meal: Fish oil: Lipid metabolism: TAG: Adiposity: Visceral fat: Atlantic salmon

Farmed Atlantic salmon (Salmo salar $\mathrm{L}$.) have traditionally been fed diets containing major amounts of fish oil and fish meal. The steady increase in aquaculture production volume of $8-10 \%$ per year ${ }^{(1)}$ has resulted in an increased use of alternative proteins and oils in aqua feeds. Vegetable oils are recognised as suitable alternatives to fish oils ${ }^{(2,3)}$. Vegetable oils are, however, devoid of marine $n$-3 PUFA (EPA (20:5n-3), docosapentaenoic acid (22:5n-3) and DHA (22:6n-3)) while the levels of linoleic acid (18:2n-6) and monoene fatty acids are usually high, resulting in low dietary $n-3: n-6$ ratios. Likewise, sustainable alternatives to fish meal are included among plant protein sources, such as vegetable meals, with protein contents of 20 to $50 \%{ }^{(4)}$. However, the indispensable amino acid profile of plant proteins differs from that of fish meal. Sensible blending of different protein sources are adopted to complete the indispensable amino acid composition, while low levels of selected crystalline amino acids may also be added to fulfil amino acid requirements.

Studies on metabolic effects when replacing marine ingredients have concentrated either on fish ill $^{(3-5)}$ or fish meal replacement $^{(6-8)}$ independently. Typically, replacing fish oil with vegetable oils and thus decreasing marine $n$ - 3 PUFA and the $n-3: n-6$ ratio as well as increasing oleic acid (18: $1 n-9)$ has been reported to increase hepatic lipid stores in Atlantic salmon $^{(9)}$, particularly at low water temperatures ${ }^{(10)}$. Plasma cholesterol levels have been reported to decrease, whereas plasma TAG was unaffected by fish oil replacement ${ }^{(9)}$. Dietary fatty acid composition may also regulate the expression of genes encoding for lipid metabolism-related genes ${ }^{(5-11)}$.

Some of the most frequently used vegetable oils contain high levels of $18: 1 n-9$ which has been shown in different cell-culture systems $^{(12,13)}$ and rats ${ }^{(14)}$ to affect liver lipid and lipoprotein metabolism. EPA and DHA are reported to affect liver TAG metabolism and $\beta$-oxidation capacity ${ }^{(15-18)}$, with especially EPA having a plasma lipid-lowering effect in rats ${ }^{(19,20)}$. Furthermore, $n$-3 PUFA is suggested to inhibit the secretion of TAG-rich VLDL particles by inhibiting the rate-limiting enzyme diacylglycerol acyltransferase (EC 2.3.1.20 $)^{(15,16)}$ and by inhibiting the assembly of VLDL particles in the liver ${ }^{(21-23)}$. Several studies

Abbreviations: 40PP70VO, 40\% plant protein and 70\% vegetable oil blend; $80 \mathrm{PP} 35 \mathrm{VO}, 80 \%$ plant protein and $35 \%$ vegetable oil blend; $80 \mathrm{PP} 70 \mathrm{VO}, 80 \%$ plant protein and $70 \%$ vegetable oil blend; FABP, fatty acid binding protein; FATP, fatty acid transport protein; FMFO, $100 \%$ fish meal and $100 \%$ fish oil; LPL, lipoprotein lipase.

*Corresponding author: Dr Bente E. Torstensen, fax +4755905299 , email bente.torstensen@nifes.no 
in human subjects have shown that dietary EPA and DHA decrease plasma TAG ${ }^{(24,25)}$ and protect against $\mathrm{CHD}^{(26,27)}$.

A large body of literature presents studies on alternative protein sources to fish meal in feed to salmonids, both by using blends of plant proteins with or without amino acid supplementation, as well as total replacement of fish meal ${ }^{(6,28-32)}$. A high inclusion of dietary plant protein mix has been reported to increase lipid retention in rainbow trout ${ }^{(33)}$ whereas the opposite effects was reported in Atlantic salmon fed diets without any fish meal ${ }^{(29)}$. The reduced lipid deposition disappeared when only $5 \%$ fish meal was added to the diets ${ }^{(30)}$. Furthermore, suboptimal dietary levels of methionine in high-plant protein diets have been reported to increase liver TAG concentration, fatty acid synthase activity and the 18:1:18:0 ratio in Atlantic salmon ${ }^{(34)}$, resembling the signs observed in early stages of non-alcoholic fatty liver disease in rodent models. Suboptimal lysine in high-plant protein diets increased the whole-body lipid concentration ${ }^{(30)}$ and affected the partitioning of growth in on-growing Atlantic salmon post-smolt ${ }^{(35)}$.

Replacement of both fish oil and fish meal in diets fed to Atlantic salmon has been reported to result in decreased growth, which could only partially be explained by reduced feed intake during the first 3 months ${ }^{(36)}$. The aim of the present study, which was part of a larger project ${ }^{(36)}$, was to further elucidate the metabolic effects of the combined and maximised replacement of fish meal and fish oil with vegetable feed ingredients with special emphasis on lipid metabolism.

\section{Materials and methods}

\section{Feeding trial}

The experiments complied with the guidelines of the Norwegian Regulation on Animal Experimentation and European Community Directive 86/609/EEC, and the protocol was approved by competent individuals at the laboratory unit at the Institute of Marine Research (Bergen, Norway) and the National Animal Research Authority.

The feeding trial was carried out at the Institute of Marine Research, Matre (Matredal, Norway; $60^{\circ} 52^{\prime} \mathrm{N}, 05^{\circ} 35^{\prime} \mathrm{E}$ ) during the period from 22 June 2006 to 15 June 2007. The Atlantic salmon were obtained from AkvaGen A/S (Tingvoll, Norway). In June 2006, approximately 6000 smolt with a mean weight of 355 (SD 92) g were distributed equally into twelve $10 \mathrm{~m}^{3}$ indoor fibreglass tanks containing $7 \mathrm{~m}^{3}$ seawater, with a continuous flow-through (about 52 litres $/ \mathrm{min}$ ) of seawater (salinity $34.9 \mathrm{~g} / \mathrm{l}$ ) from a deepwater inlet $(80 \mathrm{~m}$ deep, Matrefjorden). Temperature was kept constant at $8.9 \pm 0 \cdot 1^{\circ} \mathrm{C}$, with continuous recording and an automatic record system. $\mathrm{O}_{2}$ was also automatically recorded in the outlet water and was never decreased below $80 \%$ saturation. The fish were acclimatised to the experimental conditions for 2.5 weeks before being fed the experimental diets on 22 June 2006. Fish in three randomised tanks were fed four different extruded diets: (1) a diet with maximum inclusion of fish meal (FM) and fish oil (FMFO); (2) a diet with an estimated safe maximum replacement of both fish meal and fish oil with plant meal ( $80 \%$ plant protein) and vegetable oil $(70 \%$ vegetable oil) (80PP70VO); (3) a diet with half the maximum replacement with plant meal and maximum replacement with vegetable oil (40PP70VO); and (4) a diet with maximum replacement with plant meal and half the maximum replacement with vegetable oil (80PP35VO). Diets were produced by Skretting ARC (Stavanger, Norway). The four experimental diets were fed throughout the entire seawater production phase, with all diets changing in pellet size and lipid content after a 3-month feeding period (Table 1). Diet with pellet size $4 \mathrm{~mm}$ was fed to the fish from 20 June 2006 to 20 September 2006, and from 20 September 2006 to 12 June 2007 the fish were fed the $6 \mathrm{~mm}$ diets. Capelin oil (Fish Oil Nordic, Nordsildmel, Norway) was used as the dietary fish oil, and was the main source for very-long-chain highly unsaturated n-3 PUFA. A mixture of rapeseed oil, palm oil and linseed oil (55:30:15, by vol.) was used as the replacement for fish oil (Table 1). The mixture was selected to obtain a lipid profile of SFA, MUFA and n-3 PUFA as close as possible to capelin oil ${ }^{(2)}$.

As replacement for fish meal, a mixture of maize gluten, wheat gluten, soya concentrate and krill meal was used (Table 1). A small component $(<50 \mathrm{~g} / \mathrm{kg}$ ) of krill meal (Aker Seafoods ASA, Oslo, Norway) was added to the experimental diets, with the aim to improve palatability and thus voluntary feed intake ${ }^{(37,38)}$. All diets were formulated to meet nutrient requirements of fish according to the National Research Council $^{(39)}$ recommendations. After $0,3,5,8$ and 12 months fish were weighed, and the amount of feed given was adjusted according to their biomass. Fish were reared under a natural light regimen until October 2006 when a $10 \mathrm{~h}$ light $-14 \mathrm{~h}$ dark regimen was maintained throughout the winter until March 2007, when the fish returned to the natural light regimen. From June 2006 until February 2007, the feed consumption per tank was recorded daily. Fish were fed in excess twice per d (at 07.00 and 14.00 hours) with automatic feeders for $30 \mathrm{~min}$, followed by feed collection $30 \mathrm{~min}$ after each feeding. Measuring of individual weights of at least $30 \%$ of the biomass per tank and sampling of fish for whole-body analysis (six pooled fish per tank) were performed in June 2006 (initial stage), September 2006 ( $\mathrm{T}=3$ months), November 2006 ( $\mathrm{T}=5$ months), February $2007(\mathrm{~T}=8$ months) and June 2007 ( $\mathrm{T}=12$ months). Measuring individual weights of all fish at each sampling point was avoided to minimise handling stress and ensure optimal growth conditions. Growth, nutrient retention and digestibility are reported elsewhere ${ }^{(36)}$

\section{Sampling}

Samples of each experimental diet and the oil and meal ingredients used in the feeds for each feed production batch were stored at $-20^{\circ} \mathrm{C}$. From each tank, eleven fish were anaesthetised with benzocaine $(7 \mathrm{~g} / \mathrm{l})$ and killed by a blow to the head. Of these, three fish from each tank were sampled for whole-body proximate composition, plasma lipids and lipoprotein separations, and these were not fed $2 \mathrm{~d}$ before sampling. Blood was collected from the caudal vein using 
Table 1. Feed composition $(\mathrm{g} / \mathrm{kg})$ and proximate composition (fat, protein, starch, ash and DM $(\mathrm{g} 100 \mathrm{~g} / \mathrm{g}$ wet weight) and energy as kJ/g) of two pellet sizes of the four experimental diets

\begin{tabular}{|c|c|c|c|c|c|c|c|c|}
\hline \multirow{2}{*}{$\begin{array}{l}\text { Pellet size... } \\
\text { Diet... }\end{array}$} & \multicolumn{4}{|c|}{$4 \mathrm{~mm}$} & \multicolumn{4}{|c|}{$6 \mathrm{~mm}$} \\
\hline & FMFO & 80PP35VO & 40PP70VO & 80PP70VO & FMFO & 80PP35VO & 40PP70VO & 80PP70VO \\
\hline \multicolumn{9}{|l|}{ Ingredients* } \\
\hline Wheat & 127 & 110 & 104 & 111 & 157 & 123 & 127 & 124 \\
\hline Wheat gluten & - & 150 & 96 & 150 & - & 150 & 90 & 150 \\
\hline Maize gluten & - & 150 & 150 & 150 & - & 150 & 150 & 150 \\
\hline Soyabean meal extracted & - & 130 & 50 & 130 & - & 110 & 14 & 110 \\
\hline Krill meal & - & 50 & 25 & 50 & - & 50 & 25 & 50 \\
\hline LT South American & 620 & 120 & 300 & 120 & 560 & 120 & 300 & 120 \\
\hline Linseed oil & - & 17 & 30 & 30 & - & 18 & 36 & 36 \\
\hline Palm oil & - & 33 & 60 & 60 & - & 32 & 61 & 61 \\
\hline Rapeseed oil & - & 61 & 110 & 110 & - & 56 & 110 & 110 \\
\hline Fish oil (Nordic capelin oil) & 250 & 160 & 65 & 70 & 280 & 188 & 84 & 86 \\
\hline L-Lysine & - & 13 & 6 & 13 & - & - & - & - \\
\hline Histidine-HCl & - & 1 & - & 1 & - & - & - & - \\
\hline DL-Methionine & - & 1 & - & 1 & - & - & - & - \\
\hline Vitamins and minerals $†$ & 3 & 4 & 4 & 4 & 3 & 3 & 3 & 3 \\
\hline \multicolumn{9}{|l|}{ Proximate composition $(\mathrm{g} / \mathrm{kg})$} \\
\hline Fat $( \pm 5 \%) \ddagger$ & 286 & 281 & 286 & 281 & 343 & 318 & 339 & 328 \\
\hline Protein $( \pm 3 \%)$ & 431 & 442 & 433 & 442 & 422 & 424 & 412 & 426 \\
\hline Ash $( \pm 3 \%)$ & 108 & $58 \cdot 2$ & $72 \cdot 4$ & 58.4 & $67 \cdot 2$ & 54.4 & 65 & 54.5 \\
\hline Starch & 85.7 & 97.4 & 97.4 & 101 & $91 \cdot 2$ & 88.4 & $80 \cdot 7$ & $86 \cdot 6$ \\
\hline $\mathrm{DM}( \pm 3 \%)$ & 928 & 939 & 932 & 943 & 923 & 925 & 924 & 932 \\
\hline Energy $(\mathrm{kJ} / \mathrm{g})$ & 238 & 249 & 245 & 248 & 251 & 254 & 254 & 253 \\
\hline
\end{tabular}

FMFO, $100 \%$ fish meal and $100 \%$ fish oil; 80 PP35VO, $80 \%$ plant protein and $35 \%$ vegetable oil blend; $40 \mathrm{PP} 70 \mathrm{VO}$, $40 \%$ plant protein and $70 \%$ vegetable oil blend; 80PP70VO, $80 \%$ plant protein and $70 \%$ vegetable oil blend; LT, low temperature

*Wheat: Statkorn, Oslo, Norway; wheat gluten: Cerestar Scandinavia AS, Copenhagen, Denmark; maize gluten: Cargill, Minneapolis, MN, USA; soyabean meal extracted: Denofa, Fredrikstad, Norway; krill meal: Aker Seafoods ASA, Oslo, Norway; LT South American: Consortio, Arequipa, Peru; linseed oil: Elbe Fetthandel GmbH, Geesthacht, Germany; palm oil: Denofa; rapeseed oil: Emmelev AS, Otterup, Denmark; fish oil: Nordsildmel, Fyllingsdalen, Norway.

† Vitamin and mineral supplementation is estimated to meet the requirements according to National Research Council ${ }^{(39)}$ recommendations.

$\ddagger$ The method uncertainty is based on internal reproducibility, analyses of reference material and between-laboratory test of quality-assured methods.

EDTA vacutainers for plasma samples for further lipoprotein separation and heparin for the plasma samples for further analyses of nutrients. At $6 \mathrm{~h}$ after the last feeding, samples were collected from five fish per tank and pooled for tissue lipid and amino acid analyses and the determination of plasma amino acids. Visceral fat index was based on the visceral weight of eight fish from each tank (totally twenty-four fish from each dietary treatment). For RNA isolation and gene expression analyses, liver and visceral adipose tissue from three fish from each tank (in total nine fish per dietary treatment and collected $6 \mathrm{~h}$ after last feeding) were sampled individually and flash-frozen on liquid $\mathrm{N}_{2}$. All samples were stored at $-80^{\circ} \mathrm{C}$ until analysed.

\section{Dietary amino acids and nitrogen metabolites in liver}

Dietary amino acids were analysed after hydrolysis in $6 \mathrm{M}-\mathrm{HCl}$ as described previously for the growth and accretion data of the present trial ${ }^{(36)}$. $\mathrm{N}$ metabolites in the liver at the end of the feeding experiment were extracted and analysed as described $^{(29)}$.

\section{Lipid extraction and fatty acid analysis}

The lipid content of diets, whole fish and flesh was determined gravimetrically as the sum of free and bound fat. Free or loosely bound fat was extracted with petroleum ether and dried at $103 \pm 1^{\circ} \mathrm{C}$. The samples were thereafter hydrolysed with $\mathrm{HCl}$ in a Tecator Soxtec Hydrolysing unit (Foss Tecator AB, Höganös, Sweden) to release the bound fat, which was extracted with petroleum ether and dried at $103 \pm 1{ }^{\circ} \mathrm{C}$. Total lipid was extracted from diets, liver and flesh by homogenisation in chloroformmethanol (2:1, v/v) with 19:0 methyl ester as the internal standard. Fatty acid methyl esters were prepared from total lipid by boron trifluoride following saponification, as described previously ${ }^{(40,41)}$. Thermo Finnegan Trace 2000 GC equipped with a fused silica capillary column was used (CP-sil 88; $50 \mathrm{~m} \times 0.32 \mathrm{~mm}$ internal diameter; Chrompak Ltd, Middelburg, The Netherlands) with temperature programming of $60^{\circ} \mathrm{C}$ for $1 \mathrm{~min}, 160^{\circ} \mathrm{C}$ for $28 \mathrm{~min}, 190^{\circ} \mathrm{C}$ for $17 \mathrm{~min}$, and finally $220^{\circ} \mathrm{C}$ for $10 \mathrm{~min}$ with all intervening temperature ramps being at $25^{\circ} \mathrm{C}$ per min. Individual methyl esters were identified by comparison with known standards and on the basis of published values ${ }^{(42)}$. Data were collected and processed using Totalchrom software (version 6.2; PerkinElmer, Waltham, MA, USA).

Lipid classes of salmon liver and diets were determined essentially as described by Jordal et al. ${ }^{(9)}$ based on Bell et $a l{ }^{(43)}$. Briefly, lipids were extracted from the liver and diets by homogenising in chloroform-methanol $(2: 1, \mathrm{v} / \mathrm{v})$ with $0 \cdot 01 \%$ butylated hydroxytoluene (BHT). The samples were filtrated, evaporated after the addition of isopropanol and dissolved in chloroform-0.01\% BHT before separation on high-performance TLC plates. Total lipid $(10 \mu \mathrm{g})$ was applied to a $10 \times 20 \mathrm{~cm}$ high-performance TLC plate that had been pre-run in hexane-diethyl ether $(1: 1, \mathrm{v} / \mathrm{v})$ and activated at $110^{\circ} \mathrm{C}$ for $30 \mathrm{~min}$. The plates were developed 
at $5.5 \mathrm{~cm}$ in methyl acetate-isopropanol-chloroform-methanol-0.25\% (w/v) aqueous $\mathrm{KCl}(25: 25: 25: 10: 9$, by vol.) to separate phospholipid classes with neutral lipids running at the solvent front ${ }^{(44)}$. After drying, the plates were developed fully in hexane-diethyl ether-acetic acid (80:20:2, by vol.) to separate neutral lipids and cholesterol. Lipid classes were visualised by charring at $160^{\circ} \mathrm{C}$ for $15 \mathrm{~min}$ after spraying with $3 \%$ copper acetate $(\mathrm{w} / \mathrm{v})$ in $8 \%(\mathrm{v} / \mathrm{v})$ phosphoric acid and identified by comparison with commercially available standards. Lipid classes were quantified by scanning densitometry using a CAMAG TLC Scanner 3 and calculated using an integrator (WinCATS-Planar Chromatography, version 1.2.0; CAMAG, Berlin, Germany). Quantitative determination (mg lipid class/g tissue) of lipid classes was performed by establishing standard equations for each lipid class within a linear area, in addition to including a standard mixture of all the lipid classes at each high-performance TLC plate for corrections between plate variations.

Plasma and lipoprotein lipids were analysed using a clinical bioanalyser (Maxmat PL analyser; MaxMat S.A., Montpellier, France) according to standardised procedures, reagents and controls. Plasma lipoproteins (VLDL, LDL and HDL) in plasma were obtained by sequential centrifugal flotation ${ }^{(45,46)}$ as described by Lie et al. ${ }^{(47)}$ using a Beckman Optima ${ }^{\mathrm{TM}} \mathrm{XL}-100 \mathrm{~K}$ Ultracentrifuge equipped with a SW41Ti rotor. The centrifugation was done at $197600 \boldsymbol{g}_{\mathrm{av}}$ and $4^{\circ} \mathrm{C}$. The density intervals were obtained by the addition of solid $\mathrm{KBr}^{(48)}$, and the run times for the separation of lipoproteins were: VLDL, density (d) $<1.015 \mathrm{~g} / \mathrm{ml}$ for $20 \mathrm{~h}$; LDL, $1.015 \mathrm{~g} / \mathrm{ml}<\mathrm{d}<1.085 \mathrm{~g} / \mathrm{ml}$ for $20 \mathrm{~h}$; and HDL, $1.085 \mathrm{~g} / \mathrm{ml}<\mathrm{d}<1.21 \mathrm{~g} / \mathrm{ml}$ for $44 \mathrm{~h}$. The lipoprotein fractions were stored at $-80^{\circ} \mathrm{C}$ until further analysis.

For gene expression analysis total RNA was isolated from $100-500 \mu \mathrm{g}$ of tissue sample by the standard TRIzol extraction method (Invitrogen Ltd, Paisley, Renfrewshire, UK) and recovered in $100 \mu \mathrm{l}$ molecular diethylpyrocarbonate (DEPC)treated water. In order to remove any possible genomic DNA contamination, the total RNA samples were pretreated using DNA-free ${ }^{\mathrm{TM}}$ DNase treatment and removal reagents kit (Ambion Inc., Austin, TX, USA) following the manufacturer's protocol.

A two-step real-time RT-PCR protocol was developed to measure the mRNA levels of the target genes in Atlantic salmon liver and visceral adipose tissue. The RT reactions were run in triplicates on ninety-six-well reaction plates with the GeneAmp PCR 9700 instrument (Applied Biosystems, Foster City, CA, USA) using TaqMan Reverse Transcription Reagent containing Multiscribe RT (50 U/ $\mu \mathrm{l})$ (N808-0234; Applied Biosystems). For efficiency calculations, twofold serial dilutions of total RNA were made. A dilution curve was recorded using four serial dilutions (250-31 ng), with each concentration being run in triplicate. The samples were analysed by quantitative RT-PCR in separate sample wells and the resulting cycle thresholds $\left(C_{t}\right)$ recorded. Total RNA input was $125 \mathrm{ng}$ in each reaction for all genes. No template control (ntc) and RT-control (a duplicate RNA sample analysis where only the RT enzyme is left out) reactions were run for quality assessment. RT-controls were not performed for each sample, but were run for each assay or gene, with the same sample as used to make the dilution curves on the ninety-six-well plates. Reverse transcription was performed at $48^{\circ} \mathrm{C}$ for $60 \mathrm{~min}$ by using oligo dT primers $(2.5 \mu \mathrm{M})$ in $50 \mu \mathrm{l}$ total volume. The final concentrations of the other reagents in the $\mathrm{RT}$ reaction were: $\mathrm{MgCl}_{2}(5.5 \mathrm{~mm})$, dNTP ( $500 \mu \mathrm{m}$ of each), 10X TaqMan RT buffer (1X), RNase inhibitor $(0.4 \mathrm{U} / \mu \mathrm{l})$ and Multiscribe RT $(1 \cdot 67 \mathrm{U} / \mu \mathrm{l})$. cDNA $(2 \cdot 0 \mu \mathrm{l})$ from each $\mathrm{RT}$ reaction for all genes was transferred to a new ninety-six-well reaction plate, and the real-time PCR run in $20 \mu \mathrm{l}$ reactions on the LightCycler ${ }^{\circledR} 480$ Real-Time PCR System (Roche Applied Sciences, Basel, Switzerland). The final concentration of the primers was $500 \mathrm{~nm}$. Real-time PCR was performed using TaqMan universal PCR master mix (LightCycler 480 SYBR Green master mix kit; Roche Applied Sciences) containing FastStart DNA polymerase, and gene-specific primers. PCR was achieved with a 5 min activation and denaturising step at $95^{\circ} \mathrm{C}$, followed by forty cycles of a $15 \mathrm{~s}$ denaturing step at $95^{\circ} \mathrm{C}$, a $60 \mathrm{~s}$ annealing step and a $30 \mathrm{~s}$ synthesis step at $72^{\circ} \mathrm{C}$. The annealing temperature and sequences for the primer pairs are presented in Table 2 .

\section{Data analyses and statistics}

Q-Gene was used for the normalisation and calculation of relative expression data ${ }^{(49)}$. Q-Gene takes into account the PCR efficacy, calculated based on dilution curves. The gene expression levels were normalised towards a reference gene. For all dietary treatments, three different reference genes

Table 2. Primers for quantitative PCR assays*

\begin{tabular}{|c|c|c|c|c|}
\hline Gene & $\begin{array}{c}\text { GenBank accession } \\
\text { number }\end{array}$ & Forward primer & Reverse primer & $\begin{array}{c}\text { Annealing } \\
\text { temperature }\left({ }^{\circ} \mathrm{C}\right)\end{array}$ \\
\hline FATP1 & CA373015/AF023258 & TGGGAGCTTGTGGGTTCAA & ACTTTCATGAGGCGGATTGG & 58 \\
\hline CD36 & AY606034 & TTTCCTGCTGCGCACCTT & GGTGCGGGTCATGAAGATTT & 54 \\
\hline LPL & gi:14582900 & GCCCGACCTTTGAGTTTGC & ACGTCCACAAAGAGAGCATCGT & 60 \\
\hline FABP3 & AY509548 & CACCGCTGACGACAGGAAA & TGCACGTGAACCATCTTACCA & 60 \\
\hline FABP11 & DR695475 & CCGCCGACGACAGAAAAA & TTTTGCACAAGGTTGCCATTT & 60 \\
\hline FABP10 & BG935057 & TTGCCCATTTTGGTGAAGGA & TGAGATGGCCCTGAGGAACT & 60 \\
\hline apoB100 & gi:854619 & TTGCAGAGACCTTTAAGTTCATTCA & TGTGCAGTGGTTGCCTTGAC & 60 \\
\hline ARP (reference gene) & AY255630 & GAAAATCATCCAATTGCTGGATG & CTTCCCACGCAAGGACAGA & 60 \\
\hline$\beta$-Actin (reference gene) & BG933897 & CCAAAGCCAACAGGGAGAAG & AGGGACAACACTGCCTGGAT & 60 \\
\hline $\mathrm{EF} 1 \mathrm{~A}_{\mathrm{B}}$ (reference gene) & BG933853 & TGCCCCTCCAGGATGTCTAC & CACGGCCCACAGGTACTG & 60 \\
\hline
\end{tabular}

FATP1, fatty acid transport protein 1 ; LPL, lipoprotein lipase; FABP, fatty acid binding protein; $A R P$, acidic ribosomal phosphoprotein; $E F 1 A_{B}$, elongation factor $1 A_{\beta}$. ${ }^{*}$ All sequences are presented as $5^{\prime}$ to $3^{\prime}$. 
were measured; acidic ribosomal protein (ARP), $\beta$-actin and elongation factor $1-\alpha \beta$ isoform $\left(E F 1 A_{B}\right)$ were the reference genes that were analysed based on previous Atlantic salmon reference gene validation ${ }^{(50)}$. The reference gene stability was tested by geNorm ${ }^{(51)}$, and all reference genes were found to have stability within acceptable limits. $\beta$-Actin, however, exhibited low PCR efficacy in liver and was hence disqualified as a reference gene. The most stable of these three reference genes $\left(\mathrm{EF} 1 \mathrm{~A}_{\mathrm{B}}\right)$ was used for normalisation with the Q-Gene software (http://www.qgene.org).

All statistical analyses were performed using the program Statistica (version 9.0; Statsoft Inc., Tulsa, OK, USA). Significant differences among dietary treatments were assessed by a one-way ANOVA ${ }^{(52)}$. Where the null hypothesis $\left(\mathrm{H}_{0}\right.$, no difference between treatments or within treatment at different time intervals) was rejected, significant differences were tested using Tukey's honestly significant difference test $(P<0 \cdot 05$; Sokal \& Rohlf $\left.{ }^{(53)}\right)$. A Kolmogorov-Smirnov test was used to assess the normality of distribution of each treatment ${ }^{(52)}$. different pellet sizes
All data were normally distributed. Dependent variables were checked for homogeneity of variance by the Levene test and transformed whenever necessary ${ }^{(52)}$.

\section{Results}

After 3 months of feeding, the pellet size was adjusted according to fish size, from $4 \mathrm{~mm}$ to $6 \mathrm{~mm}$ pellets. Lipid level increased as pellet size increased, resulting in a slightly higher lipid:protein ratio, while the ratio of plant ingredients relative to marine ingredients was kept constant. Dietary amino acids differed due to the substitution of plant protein for fish meal and reflected the amino acid composition of the different protein ingredients in the various experimental diets. The indispensable amino acids:dispensable amino acids ratio was lower in the replacement groups than in the FMFO group $^{(36)}$. The higher the inclusion level of plant protein, the lower the amount of taurine in these diets and the lower the concentration of non-amino acid-N. However, only minor

Table 3. Fatty acid composition (area \% wet weight), total fatty acids (mg/g) and amino acids ( $\mathrm{g} / 16 \mathrm{~g}$ nitrogen) of the four experimental diets at two

\begin{tabular}{|c|c|c|c|c|c|c|c|c|}
\hline \multirow{2}{*}{$\begin{array}{l}\text { Pellet size... } \\
\text { Diet... }\end{array}$} & \multicolumn{4}{|c|}{$4 \mathrm{~mm}$} & \multicolumn{4}{|c|}{$6 \mathrm{~mm}$} \\
\hline & FMFO & 80PP35VO & 40PP70VO & 80PP70VO & FMFO & 80PP35VO & 40PP70VO & 80PP70VO \\
\hline \multicolumn{9}{|l|}{ SFA } \\
\hline $14: 0$ & 4.5 & $2 \cdot 8$ & $1 \cdot 8$ & $1 \cdot 7$ & $6 \cdot 4$ & $5 \cdot 0$ & $2 \cdot 6$ & $2 \cdot 8$ \\
\hline $16: 0$ & $14 \cdot 0$ & $15 \cdot 1$ & $16 \cdot 7$ & $16 \cdot 5$ & $15 \cdot 2$ & $15 \cdot 0$ & $16 \cdot 3$ & $16 \cdot 1$ \\
\hline $18: 0$ & $2 \cdot 0$ & $2 \cdot 1$ & $2 \cdot 6$ & 2.5 & 2.5 & $2 \cdot 4$ & $2 \cdot 8$ & $2 \cdot 6$ \\
\hline Sum SFA & $21 \cdot 7$ & $21 \cdot 3$ & $22 \cdot 1$ & $21 \cdot 8$ & 25.4 & 23.5 & $22 \cdot 8$ & $22 \cdot 8$ \\
\hline \multicolumn{9}{|l|}{ Monoenes } \\
\hline $16: 1 n-7$ & $5 \cdot 3$ & 3.1 & 1.8 & 1.8 & 4.7 & $4 \cdot 1$ & 1.9 & $2 \cdot 1$ \\
\hline $18: 1 n-7$ & 3.2 & $2 \cdot 8$ & 2.5 & 2.5 & $2 \cdot 0$ & $2 \cdot 2$ & $2 \cdot 4$ & $2 \cdot 3$ \\
\hline $18: 1 n-9$ & $11 \cdot 0$ & $24 \cdot 5$ & 33.6 & 34.9 & 9.5 & $17 \cdot 6$ & $30 \cdot 0$ & 28.9 \\
\hline $20: 1 n-9$ & $9 \cdot 7$ & $6 \cdot 6$ & 3.3 & 3.5 & $6 \cdot 7$ & $5 \cdot 3$ & 3.0 & 3.3 \\
\hline $20: 1 n-11$ & 1.6 & 1.1 & 0.5 & 0.5 & 0.5 & 0.4 & 0.2 & 0.2 \\
\hline $22: 1 n-9$ & 1.9 & 1.3 & 0.7 & 0.8 & 0.9 & 1.1 & 1.3 & 1.3 \\
\hline $22: 1 n-11$ & 11.8 & $7 \cdot 8$ & 3.3 & 3.6 & $10 \cdot 4$ & $7 \cdot 7$ & 3.5 & $4 \cdot 1$ \\
\hline $24: 1 n-9$ & $1 \cdot 1$ & 0.6 & 0.3 & 0.4 & $1 \cdot 1$ & 0.8 & 0.5 & 0.5 \\
\hline Sum monoenes & 47.0 & 48.7 & $46 \cdot 3$ & 48.4 & $36 \cdot 7$ & $39 \cdot 8$ & 43.3 & 43.3 \\
\hline \multicolumn{9}{|l|}{$n-6$} \\
\hline $18: 2 n-6$ & 1.6 & 8.9 & 13.7 & 13.4 & $2 \cdot 3$ & 7.5 & $12 \cdot 8$ & $12 \cdot 7$ \\
\hline $20: 2 n-6$ & 0.3 & 0.2 & 0.0 & 0.0 & 0.3 & 0.2 & 0.1 & 0.1 \\
\hline $20: 3 n-6$ & 0.0 & 0.0 & 0.0 & 0.0 & 0.0 & 0.0 & 0.0 & 0.0 \\
\hline $20: 4 n-6$ & 0.6 & 0.3 & 0.2 & 0.1 & 0.9 & 0.5 & 0.3 & 0.3 \\
\hline Sum $n-6$ & $2 \cdot 5$ & $9 \cdot 3$ & $13 \cdot 9$ & 13.5 & 3.4 & $8 \cdot 2$ & $13 \cdot 3$ & $13 \cdot 1$ \\
\hline \multicolumn{9}{|l|}{$n-3$} \\
\hline $18: 3 n-3$ & 0.8 & $5 \cdot 7$ & $9 \cdot 1$ & 9.7 & 1.4 & $5 \cdot 3$ & 9.4 & $9 \cdot 3$ \\
\hline $18: 4 n-3$ & $2 \cdot 2$ & 1.3 & 0.7 & 0.6 & 3.5 & $2 \cdot 6$ & 1.2 & 1.3 \\
\hline $20: 3 n-3$ & 0.0 & 0.0 & 0.0 & 0.0 & 0.0 & 0.0 & 0.0 & 0.0 \\
\hline $20: 4 n-3$ & 0.6 & 0.4 & 0.2 & 0.2 & 0.7 & 0.5 & 0.2 & 0.3 \\
\hline $20: 5 n-3$ & $8 \cdot 6$ & 4.8 & 2.9 & 2.5 & $9 \cdot 8$ & 7.5 & 3.5 & 3.9 \\
\hline $22: 5 n-3$ & 1.0 & 0.5 & 0.3 & 0.3 & $1 \cdot 2$ & 0.8 & 0.4 & 0.4 \\
\hline $22: 6 n-3$ & 11.4 & $6 \cdot 1$ & 3.8 & 3.0 & 13.0 & 8.5 & $5 \cdot 0$ & 4.7 \\
\hline Sum $n-3$ & $25 \cdot 2$ & $18 \cdot 8$ & $17 \cdot 1$ & $16 \cdot 3$ & 30.5 & $26 \cdot 0$ & $19 \cdot 9$ & $20 \cdot 3$ \\
\hline$n-3: n-6$ & 9.9 & $2 \cdot 0$ & $1 \cdot 2$ & $1 \cdot 2$ & 8.9 & $3 \cdot 2$ & 1.5 & 1.6 \\
\hline Total fatty acids $(\mathrm{mg} / \mathrm{g})$ & 228 & 214 & 235 & 218 & 289 & 288 & 305 & 295 \\
\hline \multicolumn{9}{|l|}{ Amino acids ${ }^{\star}$} \\
\hline Lysine & $7 \cdot 2$ & 5.9 & $6 \cdot 2$ & $6 \cdot 0$ & $6 \cdot 8$ & $5 \cdot 3$ & $5 \cdot 7$ & 5.4 \\
\hline Methionine & $2 \cdot 9$ & $2 \cdot 2$ & $2 \cdot 3$ & $2 \cdot 4$ & $2 \cdot 6$ & 2.6 & 3.2 & $2 \cdot 5$ \\
\hline Taurine & 0.9 & 0.2 & 0.4 & 0.2 & 0.9 & 0.2 & 0.5 & 0.3 \\
\hline Non-amino acid-N & $12 \cdot 1$ & 5.5 & $5 \cdot 3$ & $6 \cdot 2$ & $12 \cdot 1$ & $4 \cdot 2$ & 3.2 & 4.3 \\
\hline
\end{tabular}

FMFO, $100 \%$ fish meal and $100 \%$ fish oil; FMFO, $100 \%$ fish meal and $100 \%$ fish oil; $80 \mathrm{PP} 35 \mathrm{VO}, 80 \%$ plant protein and $35 \%$ vegetable oil blend; $40 \mathrm{PP} 70 \mathrm{VO}, 40 \%$ plant protein and $70 \%$ vegetable oil blend; $80 \mathrm{PP} 70 \mathrm{VO}, 80 \%$ plant protein and $70 \%$ vegetable oil blend.

* Lysine, methionine and taurine $(\mathrm{g} / 16 \mathrm{~g} \mathrm{~N})$ contents of the experimental diets are listed. The rest of the dietary amino acid compositions are given in Torstensen et al. ${ }^{(36)}$. 
Table 4. Dietary phospholipid and sterol composition $(\mathrm{mg} / \mathrm{g})$ of the four experimental diets

\begin{tabular}{lllll}
\hline Diet... & FMFO & 80PP35VO & 40PP70VO & 80PP70VO \\
\hline SM & 0.9 & nd & nd & nd \\
PC & 15.4 & 6.6 & 7.9 & 7.3 \\
PI & 0.8 & nd & nd & nd \\
PS & nd & nd & nd & nd \\
PE & 2.4 & nd & 0.1 & nd \\
STEROLS & 10.6 & 10.5 & 11.0 & 11.3 \\
\hline
\end{tabular}

FMFO, $100 \%$ fish meal and $100 \%$ fish oil; 80PP35VO, $80 \%$ plant protein and $35 \%$ vegetable oil blend; $40 \mathrm{PP} 70 \mathrm{VO}, 40 \%$ plant protein and $70 \%$ vegetable oil blend; 80PP70VO, $80 \%$ plant protein and $70 \%$ vegetable oil blend; SM, sphingomyelin; nd, not detected; PC, phosphatidylcholine; PI, phosphatidylinositol; PS, phosphatidylserine; PE, phosphatidylethanolamine; STEROLS, cholesterol and phytosterol.

differences in indispensable amino acids were observed between the 4 and $6 \mathrm{~mm}$ feeds ${ }^{(36)}$. The vegetable oil blend was formulated to mimic fish oil in total SFA, MUFA and PUFA content but with no highly unsaturated $n-3$ PUFA, and this was largely achieved. Replacement of fish oil with the vegetable oil blend resulted in increased percentages of $18: 3 n-3$, $18: 2 n-6$ and $18: 1 n-9$, with concomitant decreased proportions of highly unsaturated $n-3$ PUFA and long-chain monoenoic fatty acids such as $20: 1$ and $22: 1$. These differences were quantitatively greater in the diets with the higher level of fish oil replacement, in diets 40PP70VO and 80PP70VO. In contrast to the replacement of protein sources, substitution of fish oil with the vegetable oil blend had similar effects in the 6 and $4 \mathrm{~mm}$ diets. Total levels of monoenoic fatty acids, however, were similar in the $4 \mathrm{~mm}$ diets and elevated in the $6 \mathrm{~mm}$ plant diets, mainly due to $18: 1 n$-9 (Table 3). The ash content of diets was highest in the FMFO diet and decreased with increasing plant protein inclusion (Table 1). Similarly, non-starch, ash, protein or fat DM increased when fish meal was replaced by plant protein and krill meal (Table 1).

Dietary lipid class composition was significantly affected by the raw materials used (Table 4). All phospholipids decreased with decreasing fish meal and fish oil inclusion whereas NEFA concentration increased. Total amount of sterols (cholesterol + phytosterols) in all experimental diets remained the same. The phytosterol composition of the diets is reported elsewhere (BE Torstensen, $M$ Espe and $\varnothing$ Lie, unpublished results). When quantifying lipid classes by highperformance TLC, the amount of a lipid class is dependent on the number of double bonds in the lipid class. Assuming that the difference in dietary fatty acids (Table 3) is representative also for the phospholipids, approximately $20 \%$ of the reduction in phosphatidylcholine may be due to a reduced number of double bonds.

\section{Whole-body lipid stores - adiposity}

High inclusion levels of plant proteins combined with the vegetable oil blend (80PP70VO) resulted in significantly increased whole-body lipids compared with high inclusion of plant proteins together with low vegetable oil (80PP35VO) (Fig. 1(A)). This was not reflected in total fillet lipid level (Fig. 1(B)).
Indeed, the visceral somatic index was significantly higher in fish fed 80PP70VO compared with the other dietary groups (Fig. 1(C)). It is well known that fillet and whole-fish lipid level can be positively correlated with fish weight. Fish fed 80PP70VO and 80PP35VO had significantly lower final weight $^{(36)}$ and may therefore have decreased relative fillet and whole-fish lipid level due to this. Therefore all lipid data were presented per kg fish to eliminate this confounding factor.

\section{Liver lipid stores and fatty acid composition}

Liver lipid stores (TAG) increased in fish fed the plant ingredient diets differently through the 12 months, with TAG being
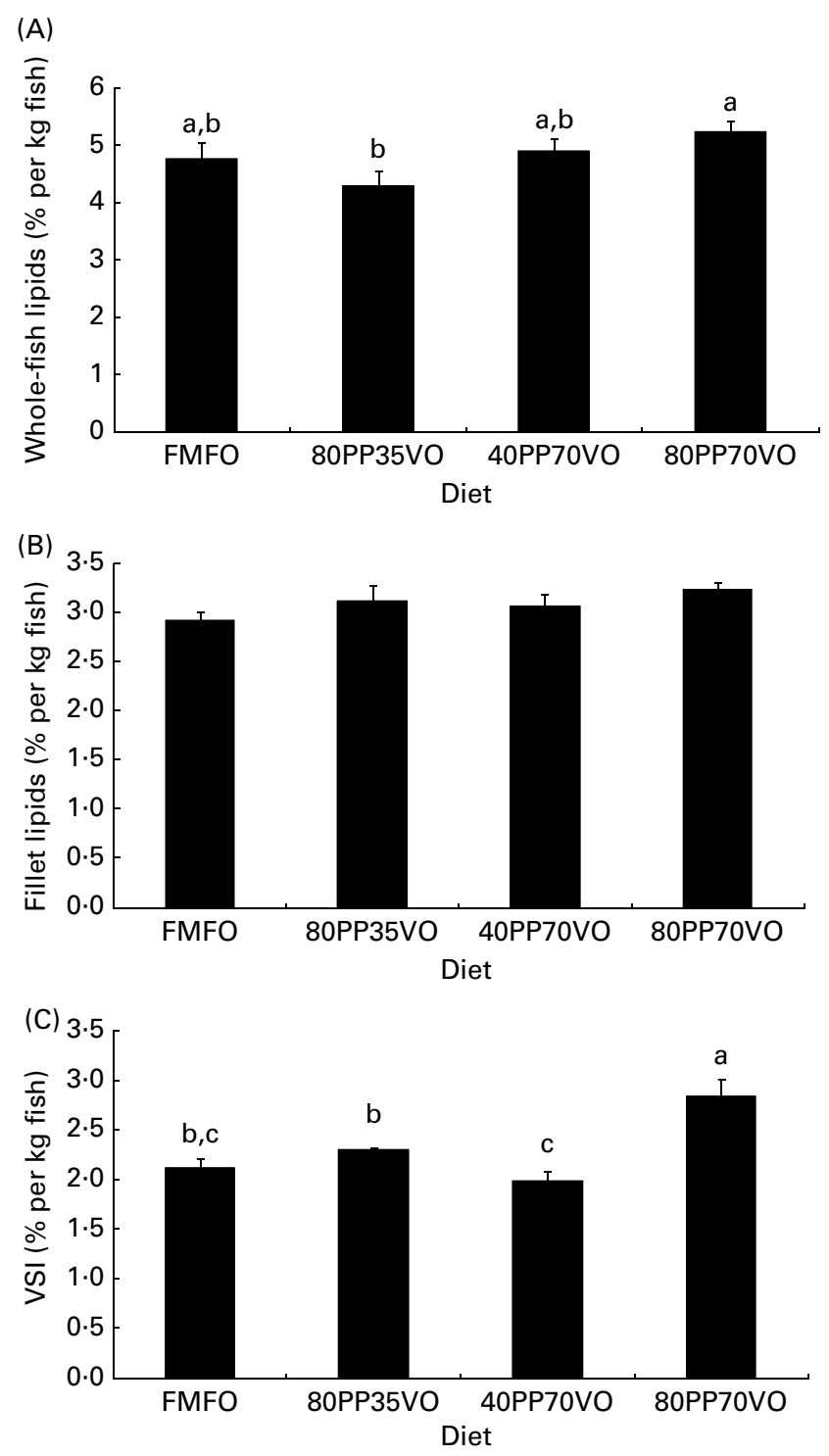

Fig. 1. Whole-fish lipid level (A), fillet lipid level (B) and visceral somatic index (VSI) (C), all corrected for differences in final fish weight, from Atlantic salmon (Salmo salar L.) fed either $100 \%$ fish meal and 100\% fish oil (FMFO), $80 \%$ plant proteins and $35 \%$ vegetable oil blend (80PP35VO), $40 \%$ plant proteins and $70 \%$ vegetable oil blend (40PP70VO) or $80 \%$ plant proteins and $70 \%$ vegetable oil blend (80PP70VO) for 12 months. Values are means $(n 3)$, with standard deviations represented by vertical bars. ${ }^{a, b, c}$ Mean values with unlike letters were significantly different $(P<0.05$; one-way ANOVA). 
more than twofold in the 80PP70VO group compared with the FMFO control after 12 months of feeding (Fig. 2). It is important to note that TAG accumulation was affected differently during the seawater period (Fig. 2). After 3 months, all groups of fish fed diets containing plant protein and vegetable oils showed significantly increased TAG concentration compared with the FMFO-fed fish. After 8 months, however, no significant differences were observed but there were large standard deviations in the 80PP70VO group. After 12 months, the combined high-plant protein and high-vegetable oil group (80PP70VO) showed significant TAG accumulation compared with the FMFO and 80PP35VO groups. Hepatic TAG level of the 40PP70VO-fed fish, however, was in between the other dietary treatments and was not statistically different. Considering that differences in liver fatty acid composition (Table 5) influence the quantification of TAG, TAG in the two $70 \mathrm{VO}$ groups would be underestimated by approximately $14 \%$ (due to $14 \%$ fewer double bonds in the livers of $70 \mathrm{VO}$ compared with fish oil-fed fish). In this case, the consequence would be even larger differences in TAG level between fish oil- and 35\% vegetable oil (35VO)-fed fish compared with the two groups of $70 \mathrm{VO}-$ fed fish.

Liver fatty acid composition was highly influenced by the dietary fatty acid composition after 3, 8 (data not shown) and 12 months of feeding (Table 5). Overall 18:1n-9, $18: 2 n-6$ and $18: 3 n-3$ increased. They were at similar levels in the two $70 \%$ vegetable oil groups whereas the marine $n-3$ fatty acids and 20:4n-6 were significantly decreased when vegetable oils replaced fish oil (Table 5). In the FMFO diets, 20:4n-6 was higher (Table 3), whereas the levels of $18: 2 n-6$ were 6 -fold higher in the $70 \%$ vegetable oil diets compared with the fish oil diet and 6-fold higher in the salmon livers. The concentration of $18: 3 n-3$, however, was almost 9-fold higher in the vegetable oil diets compared with fish oil and 6-fold higher in the salmon livers (Table 5). The 18:1n-9 content was approximately 3-fold higher in

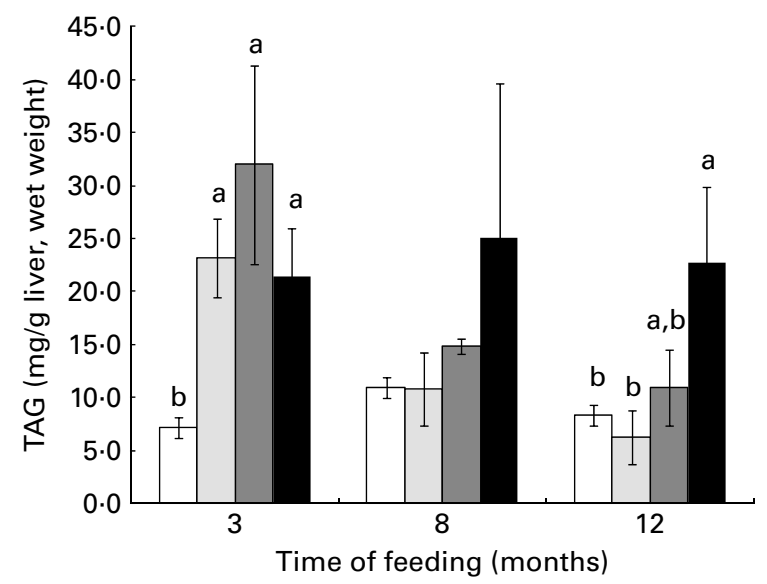

Fig. 2. Liver lipid stores (TAG) from Atlantic salmon (Salmo salar L.) fed either $100 \%$ fish meal and $100 \%$ fish oil $(\square), 80 \%$ plant proteins and $35 \%$ vegetable oil blend $(\square), 40 \%$ plant proteins and $70 \%$ vegetable oil blend $(\square)$ or $80 \%$ plant proteins and $70 \%$ vegetable oil blend (ם) for 12 months. Values are means ( $n 3)$, with standard deviations represented by vertical bars. ${ }^{a, b}$ Mean values with unlike letters were significantly different $(P<0.05$; one-way ANOVA). the $70 \%$ vegetable oil diets, whereas 2 -fold and significantly higher in the livers of salmon fed the 70VO diets compared with FMFO controls (Tables 3 and 5).

\section{Liver nitrogen metabolites}

Liver taurine concentration was significantly lower in fish fed the two diets with high plant protein inclusion (diets $80 \mathrm{PP} 35 \mathrm{VO}$ and $80 \mathrm{PP} 70 \mathrm{VO})$ at the final sampling after 12 months of feeding. The non-protein-bound glycine, serine, methionine and lysine were not different in fish fed any of the plant diets (Table 5). Liver cystathionine concentration was significantly lower in fish fed the high-plant protein, low-vegetable oil diet (80PP35VO) as compared with the fish fed the total replacement diet (80PP70VO). No significant differences in liver phosphatidylethanolamine concentration were detected in any of the dietary groups.

\section{Plasma and VLDL TAG}

Plasma and VLDL TAG significantly increased when both fish meal and fish oil were replaced with maximum levels of vegetable oil (70\%) and $80 \%$ plant protein mix (Fig. 3), being significantly higher after 3 and 12 months of feeding. The two intermediate replacement groups (80PP35VO and 40PP70VO) varied more in plasma and VLDL TAG concentration and with higher levels after 8 months compared with 12 months of feeding. There were no significant differences between 80PP35VO and 40PP70VO and FMFO or 80PP70VO at any of the three sampling periods (Fig. 3). The sampling point after 8 months of feeding exhibited less difference between the groups and no statistical significant differences were observed (Fig. 3).

\section{Expression of genes encoding lipid transport and uptake}

The increased plasma TAG in 80PP70VO compared with FMFO was opposite to the expression of the visceral adipose tissue fatty acid binding protein (FABP11), which was downregulated in visceral adipose tissue of 80PP70VO-fed fish (Fig. 4(A)). The expression of FABP11 was approximately 10-fold higher compared with lipoprotein lipase (LPL) and fatty acid transport protein (FATP) in visceral adipose tissue (Fig. 4(B)). Furthermore, the expression of cd36 was only at trace levels compared with the other lipid uptake and transport proteins measured in visceral adipose tissue (Fig. 4(B)) No changes in the expression of fatty acid uptake genes (LPL, FATP1 and cd36; Fig. 4(B)) were present, which may indicate no difference in the uptake of fatty acids in visceral adipose tissue.

In the liver, the expression of genes related to fatty acid uptake (cd36) and intracellular transport (FABP10) was not significantly affected when fish meal and fish oil were replaced with $80 \%$ plant protein and $70 \%$ vegetable oil (Fig. 5(A) and (B)); however, there seemed to be a trend of increased expression of cd36 and FABP10 in 80PP70VO-fed salmon. The level of expression of FATP1 and cd36 was comparable in liver, whereas FABP10 was expressed 100-fold 
Table 5. Liver fatty acid composition (area \%) and nitrogen metabolites ( $\mu \mathrm{mol} / 100 \mathrm{~g}$ wet weight) from Atlantic salmon (Salmo salar L.) after being fed the four experimental diets for 12 months (Mean values and standard deviations for three fish per diet)

\begin{tabular}{|c|c|c|c|c|c|c|c|c|}
\hline \multirow{3}{*}{ Diet... } & \multicolumn{8}{|c|}{ Liver, 12 months } \\
\hline & \multicolumn{2}{|c|}{ FMFO } & \multicolumn{2}{|c|}{ 80PP35VO } & \multicolumn{2}{|c|}{ 40PP70VO } & \multicolumn{2}{|c|}{ 80PP70VO } \\
\hline & Mean & SD & Mean & SD & Mean & SD & Mean & SD \\
\hline \multicolumn{9}{|l|}{ SFA } \\
\hline $14: 0$ & $2 \cdot 2^{\mathrm{a}}$ & 0.2 & $1.6^{\mathrm{b}}$ & $0 \cdot 1$ & $1 \cdot 1^{\mathrm{c}}$ & 0.1 & $1 \cdot 1^{\mathrm{c}}$ & 0.1 \\
\hline $16: 0$ & $12 \cdot 0$ & 0.5 & $13 \cdot 1$ & 0.4 & 11.6 & 1.3 & $12 \cdot 5$ & 0.4 \\
\hline $18: 0$ & $5 \cdot 6$ & 0.1 & $5 \cdot 6$ & 0.3 & 5.9 & 0.4 & $6 \cdot 4$ & 0.5 \\
\hline $20: 0$ & 0.1 & 0.1 & 0.1 & 0.1 & 0.2 & 0.0 & 0.2 & 0.1 \\
\hline Sum SFA & $22 \cdot 0$ & 0.3 & $21 \cdot 6$ & 0.7 & $19 \cdot 7$ & 1.8 & $20 \cdot 7$ & 0.8 \\
\hline \multicolumn{9}{|l|}{ Monoenes } \\
\hline $16: 1 n-7$ & $2 \cdot 1^{\mathrm{a}}$ & 0.3 & $1 \cdot 6^{\mathrm{b}}$ & 0.2 & $1 \cdot 3^{\mathrm{b}}$ & 0.3 & $1 \cdot 3^{\mathrm{b}}$ & 0.1 \\
\hline $18: 1 n-7$ & $2 \cdot 5^{\mathrm{a}}$ & 0.1 & $2 \cdot 2^{b}$ & 0.1 & $2 \cdot 2^{b}$ & 0.2 & $2 \cdot 0^{\mathrm{b}}$ & 0.1 \\
\hline $18: 1 n-9$ & $10 \cdot 5^{c}$ & 0.8 & $16 \cdot 6^{b}$ & $1 \cdot 1$ & $22 \cdot 3^{a}$ & $6 \cdot 1$ & $22 \cdot 7^{a}$ & 0.5 \\
\hline $18: 1 n-11$ & $2 \cdot 0^{\mathrm{a}}$ & 0.2 & $1.4^{\mathrm{b}}$ & 0.1 & $0.8^{\mathrm{c}}$ & 0.1 & $0.8^{\mathrm{c}}$ & 0.1 \\
\hline $20: 1 n-9$ & $4 \cdot 2$ & 0.2 & 3.7 & 0.5 & 4.0 & 0.6 & $3 \cdot 7$ & 0.2 \\
\hline $22: 1 n-9$ & 0.3 & $0 \cdot 1$ & 0.3 & 0.0 & 0.3 & 0.1 & 0.4 & 0.1 \\
\hline $22: 1 n-11$ & $2 \cdot 1^{\mathrm{a}}$ & 0.3 & $1.4^{b}$ & 0.2 & $0.8^{\mathrm{c}}$ & 0.1 & $0.7^{c}$ & 0.1 \\
\hline $24: 1 n-9$ & 0.3 & 0.1 & 0.3 & 0.1 & 0.3 & 0.1 & 0.2 & 0.1 \\
\hline Sum monoenes & 25.5 & $2 \cdot 0$ & 28.4 & $2 \cdot 0$ & $32 \cdot 7$ & $7 \cdot 4$ & $32 \cdot 6$ & 0.6 \\
\hline \multicolumn{9}{|l|}{$n-6$} \\
\hline $18: 2 n-6$ & $1.3^{\mathrm{c}}$ & $0 \cdot 1$ & $5 \cdot 1^{b}$ & $0 \cdot 1$ & $6 \cdot 9^{\mathrm{a}}$ & 0.7 & $6 \cdot 7^{\mathrm{a}}$ & 0.3 \\
\hline $20: 2 n-6$ & $0.5^{c}$ & 0.1 & $1.4^{\mathrm{b}}$ & 0.1 & $2 \cdot 0^{\mathrm{a}}$ & 0.1 & $2 \cdot 0^{\mathrm{a}}$ & 0.1 \\
\hline $20: 3 n-6$ & $0.2^{d}$ & 0.0 & $0.4^{\mathrm{c}}$ & 0.0 & $0.6^{\mathrm{b}}$ & 0.1 & $0 \cdot 8^{\mathrm{a}}$ & 0.1 \\
\hline $20: 4 n-6$ & $3.5^{\mathrm{a}}$ & 0.3 & $2 \cdot 5^{\mathrm{b}}$ & 0.2 & $2 \cdot 4^{\mathrm{b}}$ & 0.6 & $1.9^{\mathrm{b}}$ & 0.1 \\
\hline Sum $n-6$ & $5 \cdot 5^{\mathrm{a}}$ & 0.3 & $9 \cdot 4^{\mathrm{b}}$ & 0.2 & $12 \cdot 0^{c}$ & 0.4 & $11 \cdot 4^{c}$ & 0.5 \\
\hline \multicolumn{9}{|l|}{$n-3$} \\
\hline $18: 3 n-3$ & $0.6^{\mathrm{c}}$ & 0.0 & $2 \cdot 1^{\mathrm{b}}$ & $0 \cdot 1$ & $3 \cdot 3^{\mathrm{a}}$ & 0.5 & $2 \cdot 8^{\mathrm{a}}$ & 0.2 \\
\hline $18: 4 n-3$ & $0.4^{\mathrm{a}}$ & $0 \cdot 1$ & $0.2^{\mathrm{b}}$ & $0 \cdot 1$ & $0.2^{\mathrm{b}}$ & 0.0 & $0 \cdot 2^{b}$ & 0.0 \\
\hline $20: 3 n-3$ & $0.2^{\mathrm{c}}$ & 0.0 & $0.6^{\mathrm{b}}$ & $0 \cdot 1$ & $1.0^{\mathrm{a}}$ & 0.1 & $0.9^{\mathrm{a}}$ & 0.1 \\
\hline $20: 4 n-3$ & $1 \cdot 8^{\mathrm{a}}$ & $0 \cdot 1$ & $1.5^{\mathrm{b}}$ & 0.0 & $1.4^{\mathrm{b}}$ & 0.1 & $1 \cdot 3^{b}$ & 0.1 \\
\hline $20: 5 n-3$ & $9 \cdot 6^{a}$ & 0.3 & $7.9^{b}$ & 0.2 & $6 \cdot 2^{c}$ & 1.2 & $6 \cdot 9^{\mathrm{c}}$ & 0.5 \\
\hline $22: 5 n-3$ & $4 \cdot 2^{a}$ & 0.1 & $3 \cdot 2^{b}$ & 0.3 & $2 \cdot 3^{c}$ & 0.6 & $2 \cdot 3^{\mathrm{c}}$ & 0.2 \\
\hline $22: 6 n-3$ & $25 \cdot 8^{a}$ & 1.4 & $22 \cdot 6^{a, b}$ & 0.8 & $19 \cdot 6^{b}$ & $4 \cdot 2$ & $19 \cdot 5^{\mathrm{b}}$ & 0.2 \\
\hline Sum $n-3$ & $42 \cdot 5^{\mathrm{a}}$ & 1.5 & $38 \cdot 3^{a, b}$ & $1 \cdot 1$ & $34.0^{\mathrm{b}}$ & 5.5 & $33.9^{\mathrm{b}}$ & 0.3 \\
\hline$n-3: n-6$ & $7 \cdot 6^{a}$ & 0.2 & $4 \cdot 1^{\mathrm{b}}$ & $0 \cdot 1$ & $2.9^{c}$ & 0.5 & $3 \cdot 0^{c}$ & 0.1 \\
\hline Remaining fatty acids & 4.4 & 0.1 & $2 \cdot 3$ & 0.1 & $1 \cdot 7$ & 0.3 & 1.3 & 0.1 \\
\hline \multicolumn{9}{|l|}{$\mathrm{N}$ metabolites } \\
\hline Lysine & $164^{\mathrm{a}}$ & 14 & $137^{\mathrm{a}}$ & 21 & $130^{\mathrm{a}}$ & 7 & $137^{\mathrm{a}}$ & 14 \\
\hline Methionine & $58^{\mathrm{a}}$ & 7 & $58^{\mathrm{a}}$ & 7 & $54^{\mathrm{a}}$ & 6 & $57^{\mathrm{a}}$ & 4 \\
\hline Glycine & $373^{a}$ & 27 & $386^{a}$ & 13 & $360^{\mathrm{a}}$ & 13 & $332^{\mathrm{a}}$ & 13 \\
\hline Serine & $247^{\mathrm{a}}$ & 29 & $228^{\mathrm{a}}$ & 10 & $200^{a}$ & 19 & $219^{a}$ & 19 \\
\hline Cystathionine & $15^{\mathrm{a}, \mathrm{b}}$ & 3 & $7^{b}$ & 2 & $12^{\mathrm{a}, \mathrm{b}}$ & 2 & $21^{a}$ & 2 \\
\hline Phosphatidylethanolamine & $35^{\mathrm{a}}$ & 1 & $35^{\mathrm{a}}$ & 3 & $38^{a}$ & 3 & $33^{a}$ & 1 \\
\hline Taurine & $1383^{a}$ & 24 & $927^{\mathrm{b}}$ & 64 & $1327^{\mathrm{a}}$ & 16 & $943^{\mathrm{b}}$ & 96 \\
\hline
\end{tabular}

FMFO, $100 \%$ fish meal and 100\% fish oil; 80PP35VO, $80 \%$ plant protein and $35 \%$ vegetable oil blend; $40 \mathrm{PP} 70 \mathrm{VO}, 40 \%$ plant protein and $70 \%$ vegetable oil blend; $80 \mathrm{PP} 70 \mathrm{VO}, 80 \%$ plant protein and $70 \%$ vegetable oil blend.

a,b,c,d Mean values within a row with unlike superscript letters were significantly different $(P<0.05$; one-way ANOVA).

higher. The expression of the gene encoding for apoB100, being a part of the VLDL particle, was significantly up-regulated in the 80PP70VO-fed fish compared with the FMFO-fed fish, while the intermediate groups (80PP35VO and 40PP70VO) were in between (Fig. 5(C)). The expression of LPL in the liver was not affected by dietary plant raw materials (data not shown).

\section{Discussion}

Replacing fish meal and fish oil with high levels of a plant protein mixture and vegetable oil blend resulted in increased overall adiposity in Atlantic salmon post-smolt including increased visceral adipose tissue, liver lipids and plasma
TAG contents after 12 months of feeding. Intermediate replacement levels (40PP70VO and 80PP35VO) did not have the same effects, indicating that Atlantic salmon metabolism was affected in such a way that the fish developed increased adiposity through interactions between high levels of plant protein and vegetable oil inclusion. To our knowledge, no previous studies have been performed with combined high replacement of fish meal and fish oil in Atlantic salmon focusing on fish lipid metabolism and deposition following a long-term feeding experiment. Thus, the present study has demonstrated for the first time the interaction between plant proteins and vegetable oils in the lipid metabolism of fish. In mammalian models, reports show that either protein or lipid source affects lipid deposition and metabolism ${ }^{(54-58)}$, 

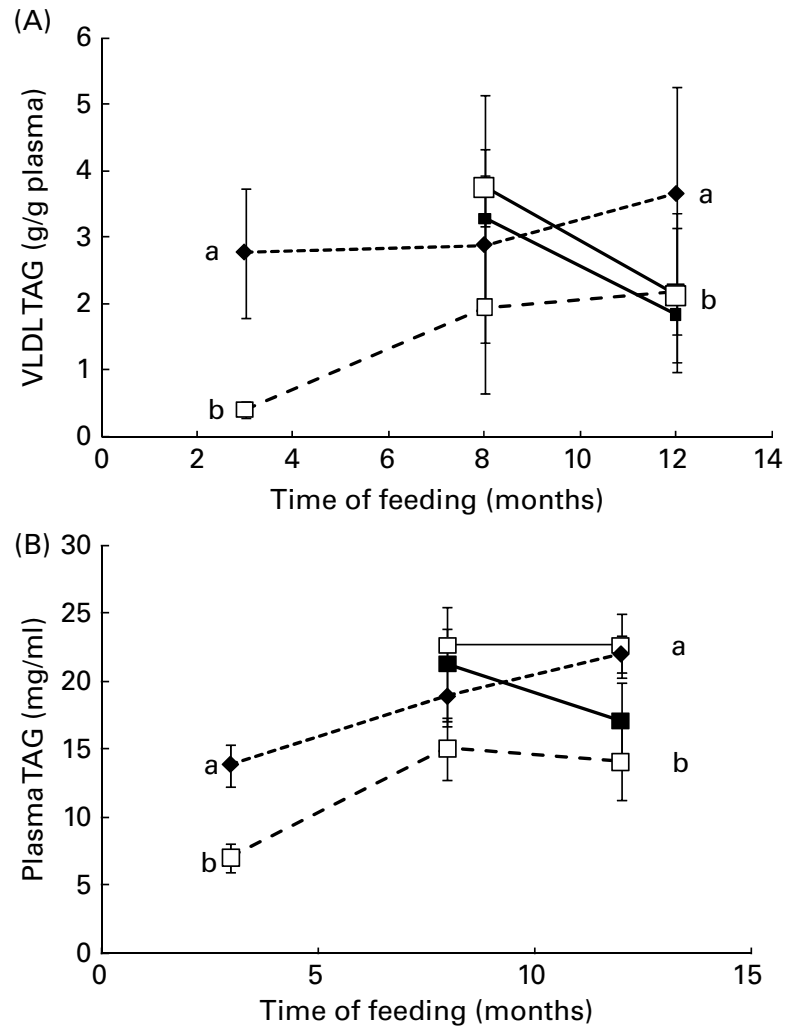

Fig. 3. Plasma TAG (mg/ml) (A) and VLDL TAG (mg TAG/g plasma) (B) after 3 months from Atlantic salmon (Salmo salar L.) fed either $100 \%$ fish oil (FMFO; -- $\square--$ ) or $80 \%$ plant proteins and $70 \%$ vegetable oil blend (80PP70VO; - - - -), and after 8 and 12 months from Atlantic salmon fed either FMFO, $80 \%$ plant proteins and $35 \%$ vegetable oil blend (80PP35VO; - $\square-$ ) or $40 \%$ plant proteins and $70 \%$ vegetable oil blend (40PP70VO; - -) or 80PP70VO. Values are means $(n 3)$, with standard deviations represented by vertical bars. Statistical differences within each time point were tested by one-way ANOVA. ${ }^{a, b}$ Mean values with unlike letters were significantly different $(P<0.05)$. No letters were assigned for groups not being significantly different from the other groups (i.e. 80PP35VO and 40PP70VO).

but even in these models the combined effect was very seldom studied ${ }^{(59)}$

Atlantic salmon fed high levels of both plant protein and vegetable oil seem to store significantly more lipids in visceral adipose tissue. In rodents, fish oil is known to decrease adiposity through reducing the adipocyte cell size and thereby improving insulin sensitivity and decreasing the release of $\mathrm{NEFA}^{(60)}$. Atlantic salmon adipocytes decrease their lipid accumulation when stimulated with marine $n-3$ fatty acids compared with $18: 1 n-9$ in vitro ${ }^{(61)}$ and this negatively correlated with FATP1 expression, indicating a role of FATP1 in adipocyte lipid accumulation ${ }^{(62)}$. The suppression of TAG accumulation by $n-3$ PUFA has also been reported in studies with 3T3-L1 pre-adipocytes ${ }^{(63)}$, and in mammalian studies where $n$-3 PUFA limits the hypertrophy of fat depots compared with high-fat diets containing SFA ${ }^{(64)}$. Hence, in several rodent models $n$-3 PUFA decreased adipocyte differentiation $^{(65)}$ and reduced fat accumulation ${ }^{(66-69)}$. However, although differences in dietary $n$-3 PUFA levels may be an important factor in the development of visceral adipose lipid accumulation also in Atlantic salmon, dietary fatty acids alone cannot explain the lipid accumulation in the 80PP70VO group since 40PP70VO had the same dietary fatty acid composition and fish oil level but not the same visceral lipid accumulation. The present increased visceral lipid levels in 80PP70VO-fed salmon indicate that although known requirement levels were met in the current diets, combined decreased levels of fish oil together with low fish meal levels induce metabolic changes resembling lysine deficiency $^{(30)}$ and/or $n-3$ PUFA deficiency at dietary levels considered adequate based on current knowledge ${ }^{(39)}$. Thus, adequate dietary levels of one critical nutrient (for example, methionine and lysine or taurine or EPA and DHA) to avoid the development of fatty liver and or reduce visceral adiposity may be underestimated when other critical nutrients (for example, methionine or EPA and DHA) are available. This synergistic effect when high levels of plant proteins and vegetable oils replace fish meal and fish oil clearly shows the importance for nutrient requirement studies taking nutrient interaction effects into account when marine ingredients are replaced.

Visceral fat levels increased, whereas the expression of the gene encoding for FABP11 decreased in visceral adipose tissue when salmon were fed 80PP70VO. Down-regulation of FABP11 has also previously been reported in visceral adipose tissue and myosepta of Atlantic salmon fed a $100 \%$ vegetable oil blend ${ }^{(11)}$. In mammals it is well established that the adipocyte FABP (AFABP/aP2) forms a physical complex with hormone-sensitive lipase that affects basal and
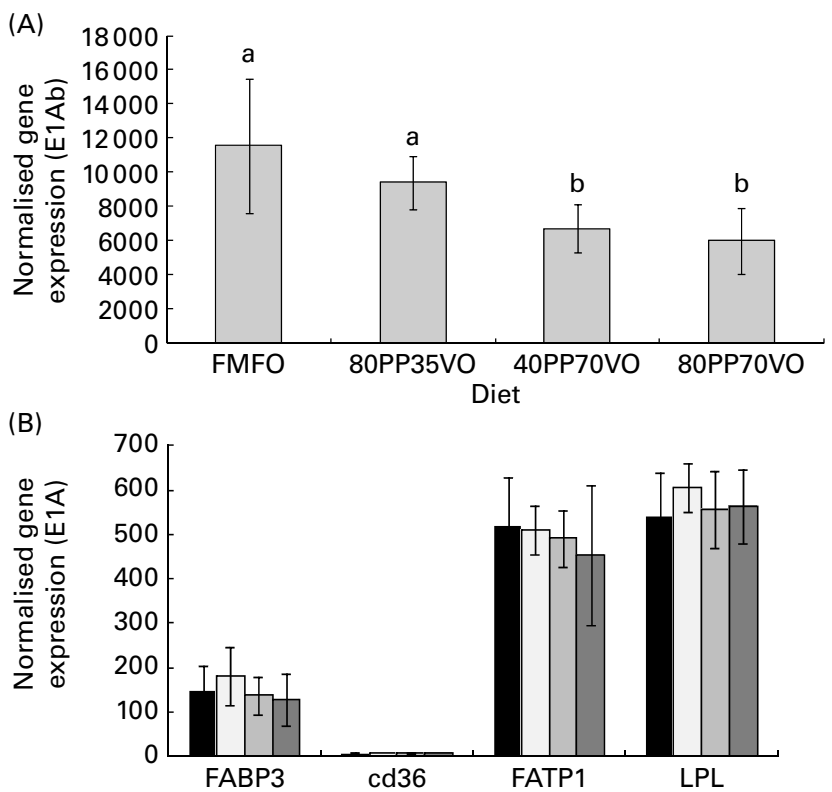

Fig. 4. Normalised gene expression levels (normalised against the reference gene elongation factor $1 \alpha_{B}\left(E F 1 A_{B}\right)$ ) of fatty acid binding protein $11(A)$ and of fatty acid binding protein 3 (FABP3), cd36, fatty acid transport protein 1 (FATP1) and lipoprotein lipase (LPL) (B) in visceral adipose tissue from Atlantic salmon (Salmo salar L.) fed either $100 \%$ fish meal and $100 \%$ fish oil (FMFO; $\square$ ), $80 \%$ plant proteins and $35 \%$ vegetable oil blend (80PP35VO; $\square$ ), $40 \%$ plant proteins and $70 \%$ vegetable oil blend (40PP70VO; $\square$ ) or $80 \%$ plant proteins and $70 \%$ vegetable oil blend (80PP70VO; $\square$ ) for 12 months. Values are means, with $95 \% \mathrm{Cl}$ represented by vertical bars. ${ }^{a, b}$ Mean values with unlike letters were significantly different $(P<0.05$; one-way ANOVA). 
(A)

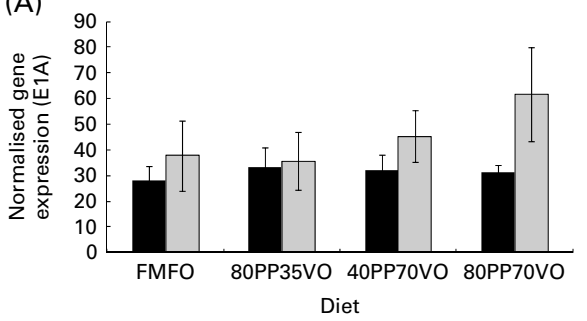

(B)

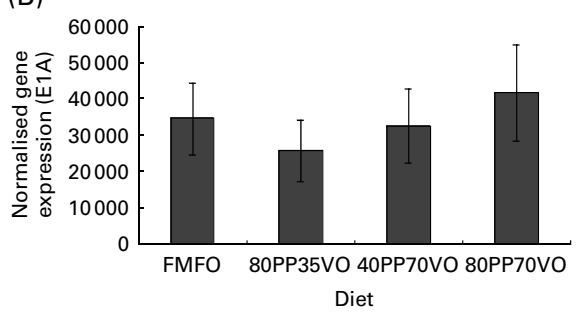

(C)

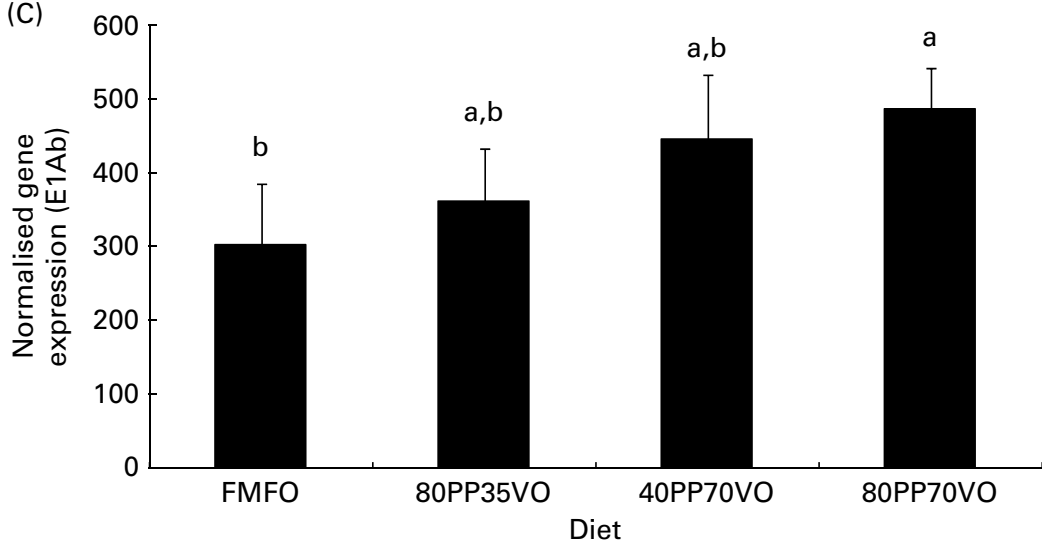

Fig. 5. Normalised gene expression levels (normalised against the reference gene elongation factor $1 \alpha_{B}\left(E F 1 A_{B}\right)$ ) of fatty acid transport protein $1(\mathbb{\square})$ and cd36 ( $\square$ ) (A), fatty acid binding protein 10 (B) and apoB100 (C) in the liver from Atlantic salmon (Salmo salar L.) fed either 100\% fish meal and 100\% fish oil (FMFO), $80 \%$ plant proteins and $35 \%$ vegetable oil blend ( $80 \mathrm{PP} 35 \mathrm{VO}$ ), $40 \%$ plant proteins and $70 \%$ vegetable oil blend (40PP70VO) or $80 \%$ plant proteins and $70 \%$ vegetable oil blend (80PP70VO) for 12 months. Values are means, with $95 \% \mathrm{Cl}$ represented by vertical bars. ${ }^{\mathrm{a}, \mathrm{b}}$ Mean values with unlike letters were significantly different $(P<0.05$; one-way ANOVA).

hormone-stimulated adipocyte fatty acid efflux ${ }^{(70,71)}$ and specifically that knock-down of AFABP in mice resulted in decreased adipocyte fatty acid efflux ${ }^{(71)}$. Although not yet studied in Atlantic salmon, the adipocyte-specific FABP in Atlantic salmon $(\mathrm{FABP} 11)^{(11,72)}$ may have a similar function of regulating the adipocyte efflux of NEFA. The down-regulation of FABP11 expression, but not of the genes encoding for fatty acid uptake (FATP1, LPL, cd36), indicate that the mechanism of increased lipid level in the visceral adipose tissue of 80PP70VO-fed salmon was mainly decreased efflux of lipids from the adipose tissue rather than increased uptake.

Atlantic salmon fed high levels of both plant protein and vegetable oil had significantly increased plasma, VLDL and liver TAG levels. In contrast, completely replacing fish oil with vegetable oils in diets with high dietary fish meal inclusions was reported to have no effect on plasma and lipoprotein TAG concentration in Atlantic salmon, but significantly increased liver $\mathrm{TAG}^{(9)}$ and especially so at low water temperatures $^{(10)}$. This was confirmed in the 40PP70VO group of the present study, but only after 3 months of feeding. Importantly, the liver TAG stores developed during the 12 months' experiment, with all fish meal and fish oil replacement groups having significantly higher hepatic TAG levels after 3 months, whereas after 8 months no significant differences appeared due to high variation in the 80PP70VO group. After 12 months the liver TAG concentration from fish fed 80PP70VO was almost twofold higher than the other dietary groups, being statistically different from 80PP35VO- and FMFO-fed fish. Ruyter et al. ${ }^{(10)}$ demonstrated the importance of water temperature for liver TAG storage when fish oil was replaced by soyabean oil. However, no increase in liver lipids was detected at $12^{\circ} \mathrm{C}$ but was present at $5^{\circ} \mathrm{C}$. The present experiment was performed at a constant temperature at $9^{\circ} \mathrm{C}$, which may explain the initial effects in the 80PP35VO and 40PP70VO groups that stabilised after 8 and 12 months of feeding. In the 80PP70VO-fed salmon, however, hepatic TAG accumulation was not reversed and was continuously increased also after 12 months of feeding at $9^{\circ} \mathrm{C}$, indicating a synergistic effect of plant proteins and vegetable oil resulting in a metabolic imbalance which was independent of temperature.

Also, limitations in the indispensable amino acids lysine and methionine affect the lipid stores in post-smolt Atlantic salmon $^{(30,34,35)}$. Suboptimal dietary levels of methionine were reported to increase liver TAG concentration, fatty acid synthase activity and the 18:1:18:0 fatty acid ratio in Atlantic salmon, but had no impact on plasma $\mathrm{TAG}^{(34)}$. Lysine limitation in post-smolt Atlantic salmon did not affect plasma or liver TAG or the fatty acid composition. Carcass lipid, however, increased upon lysine limitation ${ }^{(30)}$, whereas neither liver nor muscle fat increased ${ }^{(35)}$, indicating increased viscera adipose stores. Dietary levels of indispensible amino acids, including lysine and methionine, in the present study were similar in all diets and all were above defined requirements for on-growing Atlantic salmon ${ }^{(36)}$. Obviously, the arbitrary voluntary feed intake will affect the availability of nutrients for general metabolism. As reported by Torstensen et al. ${ }^{(36)}$, Atlantic salmon fed 80PP70VO had decreased voluntary feed 
intake and thus growth during the first 3 months of the experiment, resulting in significantly lower final body weight (about 17\% lower than FMFO-fed fish). However, the voluntary feed intake was equal in all treatment groups thereafter until the final sampling, indicating that it was not lower intake of indispensable amino acids that could explain the increased liver TAG at the end of the experiment. We have found that liver concentrations of neither free methionine ${ }^{(34)}$ nor lysine ${ }^{(35)}$ were affected by limitations in these amino acids. However, postprandial plasma concentration after $5 \mathrm{~h}$ was significantly affected by both lysine and methionine limitations ${ }^{(34,35)}$. In the present study plasma free lysine was about half in the fish meal and fish oil replacement groups as compared with the FMFO-fed fish, but no differences between any of the replacement diets were present (FMFO, $410 \mu \mathrm{mol} / 1$; 80PP35VO, 40PP70VO and 80PP70VO, range $210-240 \mu \mathrm{mol} / \mathrm{l})$. On the other hand, only the fish fed the 80PP35VO diet had significantly less plasma free methionine $(140 \mu \mathrm{mol} / \mathrm{l})$ as compared with 80PP70VO- $(250 \mu \mathrm{mol} / \mathrm{l})$ and FMFO-fed fish $(190 \mu \mathrm{mol} / \mathrm{l})$. Therefore it is unlikely that deprivation of indispensable amino acids explains the fat accumulation in the liver of fish fed 80PP70VO. However, taurine concentration was lower in both diets containing the low level of fish meal inclusion (80PP). Although Atlantic salmon has the capacity to synthesise taurine through transsulfuration $^{(73)}$, liver taurine concentration was still significantly lower in fish fed these diets after 12 months of feeding. Cystathionine concentration in liver, the first metabolite following the rate-limiting enzyme in trans-sulfuration ${ }^{(74)}$, was also affected; however, it was only significantly decreased in fish fed 80PP35VO. This may indicate that trans-sulfuration was affected in fish fed the diets containing high fish meal replacement. Dietary and liver taurine was significantly decreased when fish meal was replaced by plant proteins. Taurine is conjugated to bile acids in fish and improves the export of bile from the liver, and as such is linked to both the digestibility and clearance of cholesterol ${ }^{(75-77)}$. Deficiency of taurine has been reported to decrease the total bile acid excretion in faeces ${ }^{(78)}$. Increasing the bile acid concentration by dietary cholic acid in mice has been reported to decrease liver and plasma TAG concentrations ${ }^{(79)}$. The intake of protein sources high in taurine has been linked to reduced visceral lipid accumulation in rodent models ${ }^{(55)}$. However, taurine alone through reduced bile acid cannot explain the increased fat in 80PP70VO-fed fish, since 80PP35VO-fed salmon had significantly less whole-fish and visceral fat levels but the same dietary and liver taurine levels. Although methionine limitation reduced plasma and faecal bile acid concentrations in postsmolt Atlantic salmon, the reduction did not reach statistical difference ${ }^{(80)}$. Also, enrichment with crystalline DL-methionine did not increase plasma bile acids significantly in post-smolt Atlantic salmon ${ }^{(34)}$. In juvenile Atlantic salmon, on the other hand, addition of taurine reduced the whole-body lipid:protein ratio ${ }^{(81)}$. Since the two dietary groups where fish meal was replaced by $80 \mathrm{PP}$ had the same dietary amino acid levels but not the same response regarding whole-body and visceral fat levels, it is not likely that differences in bile acid concentration alone explain the increased visceral mass in the present study. Overall, these results indicate that at low EPA and DHA, combined with possible suboptimal levels of amino acids, the requirements of lysine and methionine increase compared with plant protein diets in which fish oil constitutes the lipid source ${ }^{(34)}$. However, since no difference in the liver 18:1:18:0 ratio was observed, firm conclusions cannot be drawn, and further studies are required to elucidate the potential role of dietary amino acids on increased liver TAG in fish meal and fish oil replacement diets.

The three replacement diets contained about half the amount of phospholipids as compared with the FMFO control diet. The lower phosphatidylcholine may interact with protein metabolism because during low dietary choline or phosphatidylcholine intake the animals are able to synthesise phosphatidylcholine from phosphatidylethanolamine through three successive methylation reaction in the liver ${ }^{(82,83)}$ In the present study liver phosphatidylethanolamine was similar in all groups, indicating similar phosphoethanolamine synthetase (pemt) activity and hence endogenous synthesis of phosphatidylcholine. However, in the present study neither phosphoethanolamine synthetase activity nor $S$-adenosylmethionine or choline status was analysed. On the other hand, we have previously reported that methionine availability affected liver $S$-adenosylmethionine ${ }^{(73)}$ and reduced liver pemt activity (M Espe, EM Hevrøy and B Liaset, unpublished results). Furthermore, phospholipid deficiency and particularly choline deficiency are well-known causes of hepatic lipid accumulation and decreased plasma VLDL levels in rodents ${ }^{(84)}$, especially when methionine is also low ${ }^{(85-87)}$. The phospholipid requirement has not been established for adult fish, but is considered to be essential for optimal growth and development at juvenile stages ${ }^{(88)}$. Thus, the increased TAG accumulation in 80PP70VO-fed salmon may be due to an interaction also with dietary phospholipids. However, a classical choline deficiency decreases plasma VLDL and hence plasma TAG, which was the opposite of the effect on plasma and VLDL TAG in 80PP70VO-fed fish. Hence, decreased dietary phospholipids may play a role together with other amino acids and fatty acids in the overall increase in liver TAG and VLDL TAG.

Increases in plasma and VLDL TAG levels were found in both groups of Atlantic salmon fed diets where $80 \%$ of the fish meal protein was replaced by the plant protein mix; these increases were observed most profoundly and consistently in the 80PP70VO group. Several studies in human subjects have shown that dietary EPA and DHA decrease plasma $\mathrm{TAG}^{(24,25)}$ and protect against $\mathrm{CHD}^{(26-27)}$. More recently it was demonstrated that high dietary EPA and DHA decreased hepatic TAG secretion in Atlantic salmon compared with a standard fish oil diet and with a rapeseed oil-based diet ${ }^{(89)}$. In mammals fish oil has been demonstrated to interfere with assembly of the initial VLDL precursor particles in hepatocytes $^{(21,90,91)}$, all supporting that increased plasma TAG in the 80PP70VO-fed salmon may be a result of increased secretion of TAG-rich VLDL particles from the liver in the post-absorptive phase regulated by dietary fatty acid composition. The assembly process of hepatic VLDL in mammals is recognised to be initiated in the endoplasmic 
reticulum as soon as apoB100 is translated and translocated into the lumenal side where the elongating apoB100 polypeptide chain recruits various lipids co-translationally (for a review, see Sundaram \& $\left.\mathrm{YaO}^{(92)}\right)$. Interestingly, the gene encoding for apoB100 was increasingly expressed when the inclusion of vegetable oil and plant proteins increased. Furthermore, although not statistically significant, there was a trend towards increased fatty acid uptake and intracellular transport of fatty acids through the increased RNA expression of cd36 and FABP10 in the livers of 80PP70VO-fed Atlantic salmon. In summary, this indicates a more active hepatic fatty acid turnover, accumulation and transport of neutral lipids in high-plant protein- and vegetable oil-fed fish compared with the traditional fish oil- and fish meal-fed fish as well as the lower replacement level diets. Previous studies replacing fish oil with vegetable oil but not replacing dietary fish meal have reported no changes in plasma or VLDL $\mathrm{TAG}^{(9)}$, confirming the findings of Kjær et $a l^{(89)}$ of no differences in hepatic TAG secretion when comparing fish oil and rapeseed oil-fed fish. In post-smolt Atlantic salmon, limitation in either lysine or methionine had no significant impact on plasma $\mathrm{TAG}^{(34,35)}$. In European seabass fed plant proteinbased diets, plasma TAG was reduced as compared with fish meal-fed fish ${ }^{(6)}$. Again, significantly and consistently increased plasma and VLDL TAG levels in the combined high-plant protein- and vegetable-oil-fed fish demonstrate an interaction between dietary lipids and proteins with lipid metabolic consequences.

Intestinal lipid droplets have been reported to appear in vegetable oil-fed fish ${ }^{(10,93-95)}$, which may be due to a slower transport of lipids from the intestinal cells to the circulation. Hence, the increased plasma TAG observed in 80PP70VOfed salmon may be due to a slower lipid uptake detected $48 \mathrm{~h}$ after the last meal. Furthermore, the apparent digestibility of 16:0 was 16\% lower in 80PP70VO-fed fish compared with the other three groups ${ }^{(36)}$, possibly slightly decreasing the lipid uptake. Plasma TAG was also analysed $6 \mathrm{~h}$ after the last meal, revealing no significant differences (data not shown). This, together with the discrepancy in effect between the two high vegetable oil groups, indicates that increased plasma TAG was not solely due to a possible increased intestinal lipid accumulation in vegetable oil-fed fish.

In mammals, the metabolic syndrome is related to increased central (visceral) adiposity, increased plasma TAG, decreased HDL-cholesterol, hypertension, glucose intolerance and type 2 diabetes, which together are well-documented risk factors for $\mathrm{CVD}^{(96)}$. In conclusion, Atlantic salmon fed 80PP70VO demonstrated increased visceral adiposity, increased plasma and VLDL TAG as well as increased hepatic TAG stores and decreased plasma HDL-cholesterol levels (BE Torstensen, $\mathrm{M}$ Espe and $\varnothing$ Lie, unpublished results). Compared with the metabolic syndrome in mammals, these changes in lipid metabolism in 80PP70VO-fed Atlantic salmon together indicate a metabolic imbalance that may affect fish health and especially cardiovascular health. These issues will be investigated in further studies.

\section{Acknowledgements}

The study was funded by the IP-EU project 'AQUAMAX' (016249-2). We would like to thank Arnor Gullanger (IMR, Matre Aquaculture Research Station) for excellent fish husbandry, and the technical assistance of Jacob Wessels (NIFES) is greatly appreciated. Members of the technical staff at NIFES are thanked for excellent assistance with the chemical analysis.

Authors' responsibilities were as follows: B. E. T., M. E., I. S. and $\varnothing$. L. planned the project and feeding experiment; B. E. T., M. S. and I. S. collected samples, B. E. T. and M. S. analysed the data and wrote the manuscript; $\varnothing$. L. was project coordinator and all authors contributed to the writing process.

There are no conflicts of interest to report.

\section{References}

1. Tacon AGJ, Hasan MR \& Subasinghe RP (2006) Use of Fishery Resources as Feed Inputs for Aquaculture Development: Trends and Policy Implications. FAO Fisheries Circular no. 1018. Rome: FAO.

2. Torstensen BE, Bell JG, Rosenlund G, et al. (2005) Tailoring of Atlantic salmon (Salmo salar L.) flesh lipid composition and sensory quality by replacing fish oil with a vegetable oil blend. J Agric Food Chem 53, 10166-10178.

3. Turchini GM, Torstensen BT \& Ng WK (2009) Fish oil replacement in finfish nutrition. Rev Aquacult 1, 10-57.

4. Hertrampf JW \& Piedad-Pascual F (2000) Handbook on Ingredients for Aquaculture Feeds. Dordrecht, The Netherlands: Kluwer Academic Publishers.

5. Leaver MJ, Bautista JM, Bjornsson BT, et al. (2008) Towards fish lipid nutrigenomics: current state and prospects for fin-fish aquaculture. Rev Fish Sci 16, 73-94.

6. Dias J, Alvarez MJ, Arzel J, et al. (2005) Dietary protein source affects lipid metabolism in the European seabass (Dicentrarchus labrax). Comp Biochem Physiol A 142, 19-31.

7. Kaushik SJ \& Seiliez I (2010) Protein and amino acid nutrition and metabolism in fish: current knowledge and future needs. Aquacult Res 41, 322-332.

8. Messina M, Tulli F, Messina C, et al. (2007) Varying plant protein sources in the diet of sea bass Deicentrarchus labrax differently affects lipid metabolism and deposition. Ital J Anim Sci 6, 806-808.

9. Jordal A-EO, Lie $\varnothing$ \& Torstensen BE (2007) Complete replacement of dietary fish oil with a vegetable oil blend affect liver lipid and plasma lipoprotein levels in Atlantic salmon (Salmo salar L.). Aquacult Nutr 13, 114-130.

10. Ruyter B, Moya-Falcón C, Rosenlund G, et al. (2006) Fat content and morphology of liver and intestine of Atlantic salmon (Salmo salar): effects of temperature and dietary soybean oil. Aquaculture 252, 441-452.

11. Torstensen BE, Nanton DA, Olsvik PA, et al. (2009) Gene expression of fatty acid binding proteins (FABPs), fatty acid transport proteins (cd36 and FATP) and $\beta$-oxidation related genes in Atlantic salmon (Salmo salar L.) fed fish oil or vegetable oil. Aquacult Nutr 15, 440-445.

12. Ranheim T, Gedde-Dahl A, Rustan AC, et al. (1994) Effect of chronic incubation of $\mathrm{CaCO}-2$ cells with eicosapentaenoic acid (20:5n-3) and oleic acid (18:1n-9) on triacylglycerol production. Biochem J 303, 155-161.

13. Vegusdal A, Gjøen T, Berge RK, et al. (2005) Effect of 18:1n9, 20:5n-3 and 22:6n-3 on lipid accumulation and secretion by Atlantic salmon hepatocytes. Lipids 40, 477-486. 
14. Halvorsen B, Rustan AC, Madsen L, et al. (2001) Effects of long-chain monounsaturated and $n-3$ fatty acids on fatty acid oxidation and lipid composition in rats. Ann Nutr Metab 45, 30-37.

15. Berge RK, Madsen L, Vaagenes H, et al. (1999) In contrast with docosahexaenoic acid, eicosapentaenoic acid and hypolipidaemic derivatives decrease hepatic synthesis and secretion of triacylglycerol acyltransferase activity and stimulation of fatty acid oxidation. Biochem J 343, 191-197.

16. Madsen L, Rustan AC, Vaagenes H, et al. (1999) Eicosapentaenoic and docosahexaenoic acid affect mitochondrial and peroxisomal fatty acid oxidation in relation to substrate preference. Lipids 34, 951-963.

17. Nossen JØ, Rustan AC, Gloppestad SH, et al. (1986) Eicosapentaenoic acid inhibits synthesis and secretion of triacylglycerols by cultured rat hepatocytes. Biochim Biophys Acta 879, 56-65.

18. Willumsen N, Vaagenes H, Asiedu D, et al. (1996) Eicosapentaenoic acid but not docosahexaenoic acid (both as ethyl esters) increases mitochondrial fatty acid oxidation and upregulates 2,4-dienoyl-CoA reductase gene expression. A potential mechanism for the hypolipidemic action of fish oil in rats. Lipids 31, 579-592.

19. Frøyland L, Madsen L, Vaagenes H, et al. (1997) Mitochondrion is the principal target for nutritional and pharmacological control of triglyceride metabolism. J Lipid Res $\mathbf{3 8}$, $1851-1858$.

20. Frøyland L, Vaagenes H, Asiedu DK, et al. (1996) Chronic administration of eicosapentaenoic acid and docosahexaenoic acid as ethyl esters reduced plasma cholesterol and changed the fatty acid composition in rat blood and organs. Lipids 31, 169-178.

21. Lang CA \& Davis RA (1990) Fish oil fatty acids impair VLDL assembly and/or secretion by cultured rat hepatocytes. J Lipid Res 31, 2079-2086.

22. Brown AM, Castle J, Hebbachi AM, et al. (1999) Administration of $n-3$ fatty acids in the diets of rats directly to hepatocyte cultures results in different effects on hepatocellular ApoB metabolism and secretion. Arterioscler Thromb Vasc Biol 19, 106-114.

23. Kendrick JS \& Higgins JA (1999) Dietary fish oils inhibit early events in the assembly of very low density lipoproteins and target ApoB for degradation within the rough endoplasmatic reticulum of hamster hepatocytes. J Lipid Res $\mathbf{4 0}$, 504-514.

24. Harris WS, Connor WE \& McMurphy MP (1983) The comparative reductions of the plasma lipids and lipoproteins by dietary polyunsaturated fats: salmon oil versus vegetable oils. Metabolism 32, 179-184.

25. Nestel PJ (1990) Effects of $n$-3 fatty acids on lipid metabolism. Ann Rev Nutr 10, 149-167.

26. Bang HO, Dyerberg J \& Nielsen AB (1971) Plasma lipid and lipoprotein pattern in Greenlandic west-coast eskimos. Lancet i, 1143-1145.

27. Seierstad SL, Seljeflot I, Johansen O, et al. (2005) Dietary intake of differently fed salmon; the influence on markers of human atherosclerosis. Eur J Clin Invest 35, 52-59.

28. de Francesco M, Parisi G, Medale F, et al. (2004) Effect of long term feeding with a plant protein mixture based diet on growth and body/fillet quality traits of large rainbow trout, Oncorbynchus mykiss. Aquaculture 263, 413-429.

29. Espe M, Lemme A, Petri A, et al. (2006) Can Atlantic salmon grow on diets devoid of fish meal? Aquaculture 255 , 255-262.

30. Espe M, Lemme A, Petri A, et al. (2007) Assessment of lysine requirement for maximal protein accretion in Atlantic salmon using plant protein diets. Aquaculture 263, 168-178.
31. Gomes EF, Rema P \& Kaushik SJ (1995) Replacement of fish meal by plant proteins in the diet of rainbow trout (Oncorbynchus mykiss): digestibility and growth performance. Aquaculture 130, 177-186.

32. Kaushik SJ, Cravedi JP, Lalles JP, et al. (1995) Partial or total replacement of fish meal by soybean protein on growth, protein utilization, potential estrogenic or antigenic effects, cholesterolemia and flesh quality in rainbow trout, Oncorbynchus mykiss. Aquaculture 133, 257-274.

33. Kaushik SJ, Covès D, Dutto G, et al. (2004) Almost total replacement of fish meal by plant protein sources in the diet of a marine teleost, the European sea bass, Dicentrarchus labrax. Aquaculture 230, 391-404.

34. Espe M, Rathore RM, Du Z-Y, et al. (2010) Methionine limitation results in increased hepatic FAS activity, higher liver 18:1 to $18: 0$ fatty acid ratio and hepatic TAG accumulation in Atlantic salmon, Salmo salar. Amino Acids 39, 449-460.

35. Rathore RM, Liaset B, Hevrøy EM, et al. (2010) Lysine limitation alters the storage pattern of protein, lipid and glycogen in on-growing Atlantic salmon. Aquacult Res $\mathbf{4 1}$, e751-e759.

36. Torstensen BE, Espe M, Sanden M, et al. (2008) Novel production of Atlantic salmon (Salmo salar) protein based on combined replacement of fish meal and fish oil with plant meal and vegetable oil blends. Aquaculture 285, 193-200.

37. Gaber MMA (2005) The effect of different levels of krill meal supplementation of soybean-based diets on feed intake, digestibility, and chemical composition of juvenile Nile tilapia Oreochromis niloticus, L.J World Aquacult Soc 36, 346-353.

38. Olsen RE, Suontama J, Langmyhr E, et al. (2006) The replacement of fish meal with Antarctic krill, Euphausia superba in diets for Atlantic salmon, Salmo salar. Aquacult Nutr 12, $280-290$

39. National Research Council (1993) Nutrient Requirements of Fish. Washington, DC: National Academy Press.

40. Lie $\varnothing$ \& Lambertsen G (1991) Fatty acid composition of glycerophospholipids in seven tissues of cod (Gadus morhua), determined by combined high-performance liquid chromatography and gas chromatography. J Chromatogr 565, 119-129.

41. Torstensen BE, Frøyland L \& Lie $\varnothing$ (2004) Replacing dietary fish oil with increasing levels of rapeseed oil and olive oil - effects on Atlantic salmon (Salmo salar) tissue and lipoprotein composition and lipogenic enzyme activities. Aquacult Nutr 10, 175-192.

42. Ackman RG (1980) Fish Lipids. Farnham: Fishing News Books.

43. Bell JG, Dick JR, McVicar AH, et al. (1993) Dietary sunflower, linseed and fish oils affect phospholipid fatty acid composition, development of cardiac lesions, phospholipase activity and eicosanoid production in Atlantic salmon. Prostaglandins Leukot Essent Fatty Acids 49, 665-673.

44. Vitello F \& Zanetta J-P (1978) Thin-layer chromatography of phospholipids. J Chromatogr 166, 637-640.

45. Havel RJ, Eder HA \& Havel RJ (1955) The distribution and chemical composition of ultra-centrifugally separated lipoproteins in human sera. J Clin Invest 34, 1345-1353.

46. Aviram A (1983) Plasma lipoprotein separation by discontinuous density gradient ultracentrifugation in hyperlipoproteinemic patients. Biochem Med 30, 111-118.

47. Lie $\varnothing$, Sandvin A \& Waagboe R (1994) Transport of $\alpha$-tocopherol in Atlantic salmon (Salmo salar) during vitellogenesis. Fish Physiol Biochem 13, 241-247.

48. Warnick GR, Cheung MC \& Albers JJ (1979) Comparison of current methods for high-density lipoprotein cholesterol quantitation. Clin Chem 25, 596-604. 
49. Simon P (2003) Q-Gene: processing quantitative real-time RT-PCR data. Bioinformatics 19, 1439-1440.

50. Olsvik PA, Lie KK, Jordal A-EO, et al. (2005) Selection of normalizing genes in quantitative real time RT-PCR: a case study of Atlantic salmon. BMC Mol Biol 6, 21.

51. Vandesompele J, Preter KD, Pattyn F, et al. (2002) Accurate normalization of real-time quantitative RT-PCR data by geometric averaging of multiple internal control genes. Genome Biol 3, research0034.0031-research0034.0011.

52. Zar JH (1984) Biostatistical Analysis, pp. 253-260. Englewood Cliffs, NY: Prentice-Hall.

53. Sokal RR \& Rohlf FJ (1981) Assumptions of analysis of variance. In Biometry, pp. 392-450. New York: W.H. Freeman \& Co.

54. Gudbrandsen OA, Wergedahl H, Mork S, et al. (2006) Dietary soya protein concentrate enriched with isoflavones reduced fatty liver, increased hepatic fatty acid oxidation and decreased the hepatic mRNA level of VLDL receptor in obese Zucker rats. Br J Nutr 96, 249-257.

55. Liaset B, Madsen L, Hao Q, et al. (2009) Fish protein hydrolysate elevates plasma bile acids and reduces visceral adipose tissue mass in rats. Biochim Biophys Acta 1791 , $254-262$.

56. Nagao K \& Yanagita T (2008) Bioactive lipids in metabolic syndrome. Prog Lipid Res 47, 127-146.

57. Torres N, Torre-Villalvazo I \& Tovar AR (2006) Regulation of lipid metabolism by soy protein and its implication in diseases mediated by lipid disorders. J Nutr Biochem 17, $365-373$.

58. Tovar AR \& Torres N (2010) The role of dietary protein on lipotoxicity. Biochim Biophys Acta 1801, 367-371.

59. Wergedahl H, Gudbrandsen OA, Røst TH, et al. (2009) Combination of fish oil and fish protein concentrate reduces the plasma cholesterol level with a concurrent increase in hepatic level in high-fat-fed Wistar rats. Nutr Food Sci 25, 98-104.

60. Lombardo YB, Hein G \& Chicco A (2007) Metabolic syndrome: effects of $n-3$ PUFAs on a model of dyslipidemia, insulin resistance and adiposity. Lipids 42, 427-437.

61. Todorcević M, Vegusdal A, Gjøen T, et al. (2008) Changes in fatty acids metabolism during differentiation of Atlantic salmon preadipocytes; effects of $n-3$ and $n-9$ fatty acids. Biochim Biophys Acta 1781, 326-335.

62. Huang TS, Todorcevic M, Ruyter B, et al. (2009) Altered expression of CCAAT/enhancer binding protein and FABP11 genes during adipogenesis in vitro in Atlantic salmon (Salmo salar). Aquacult Nutr 16, 72-80.

63. Kim HK, La-Fera M, Lin J, et al. (2006) Docosahexaenoic acid inhibits adipocyte differentiation and induces apoptosis in 3T3-L1 preadipocytes. J Nutr 136, 2965-2969.

64. Belzung F, Raclot T \& Groscolas R (1993) Fish-oil $n$-3 fattyacids selectively limit the hypertrophy of abdominal fat depots in growing rats fed high-fat diets. Am J Physiol 264, R1111-R1118.

65. Okuno M, Kajiwara K, Imai S, et al. (1997) Perilla oil prevents the excessive growth of visceral adipose tissue in rats by downregulating adipocyte differentiation. J Nutr 127, 1752-1757.

66. Carlotti M, Hainault I, Guichard C, et al. (1993) Beneficialeffects of a fishoil enriched high lard diet on obesity and hyperlipemia in Zucker rats. Ann $N$ Y Acad Sci 683, 349-350.

67. Cunnane SC, Mcadoo KR \& Horrobin DF (1986) n-3 Essential fatty-acids decrease weight-gain in genetically-obese mice. Br J Nutr 56, 87-95.

68. Ikemoto S, Takahashi M, Tsunoda N, et al. (1996) High-fat diet-induced hyperglycemia and obesity in mice: differential effects of dietary oils. Metab Clin Exp 45, 1539-1546.
69. Jones PJH (1989) Effect of fatty-acid composition of dietaryfat on energy-balance and expenditure in hamsters. Can J Physiol Pharm 67, 994-998.

70. Smith AJ, Sanders MA, Juhlmann BE, et al. (2008) Mapping of the hormone-sensitive lipase binding site on the adipocyte fatty acid-binding protein (AFABP). Identification of the charge quartet on the AFABP/aP2 helix-turn-helix domain. J Biol Chem 283, 33536-33543.

71. Baar RA, Dingfelder CS, Smith LA, et al. (2005) Investigation of in vivo fatty acid metabolism in AFABP/aP2 $2^{-/-}$mice. Am J Physiol Endocrinol Metab 288, E187-E193.

72. Agulleiro MJ, André M, Morais S, et al. (2007) High transcript level of fatty acid-binding protein 11 but not of very low-density lipoprotein receptor is correlated to ovarian follicle atresia in a teleost fish (Solea senegalensis). Biol Reprod 77, 504-516.

73. Espe M, Hevrøy EM, Liaset B, et al. (2008) Methionine intake affects hepatic sulphur metabolism in Atlantic salmon, Salmo salar. Aquaculture 274, 132-141.

74. Mato JM, Corrales FJ, Lu SC, et al. (2002) S-adenosylmethionine: a control switch that regulates liver function. FASEB J 16, 15-26.

75. Bogevik AS, Tocher DR, Langmyhr E, et al. (2009) Atlantic salmon (Salmo salar) postsmolts adapt lipid digestion according to elevated dietary wax esters from Calanus finmarchius. Aquacult Nutr 15, 94-103.

76. Yamamoto T, Suzuki N, Furuita H, et al. (2007) Supplemental effect of bile salts to soybean meal-based diet on growth and feed utilization of rainbow trout Oncorhynchus mykiss. Fish Sci 73, 123-131.

77. Yokogoshi H \& Oda H (2002) Dietary taurine enhances cholesterol degradation and reduces serum and liver cholesterol concentrations in rats fed a high cholesterol diet. Amino Acids 23, 433-439.

78. Chen W, Matuda K, Nishimura N, et al. (2004) The effect of taurine on cholesterol degradation in mice fed a high-cholesterol diet. Life Sci 74, 1889-1898.

79. Watanabe M, Houten SM, Wang L, et al. (2004) Bile acids lower triglyceride levels via a pathway involving FXR, SHP, and SREBP-1C. J Clin Invest 113, 1408-1418.

80. Espe M, Liaset B, Hevrøy EM, et al. (2010) DL-Methionine enrichment in diets fed to Atlantic salmon increases apparent digestibility. Aquacult Res (epublication ahead of print version 11 November 2010).

81. Espe M, Ruohonen K \& El-Mowafi A (2011) Effect of taurine supplementation on the metabolism and body lipid-toprotein ratio in juvenile Atlantic salmon (Salmo salar). Aquacult Res (In the Press).

82. Noga AA \& Vance DE (2003) Insights into the requirement of phosphatidylcholine synthesis for liver function in mice. J Lipid Res 44, 1998-2005.

83. Vance DE (2008) Role of phosphatidylcholine biosynthesis in the regulation of lipoprotein homeostasis. Curr Opin Lipidol 19, 229-234.

84. Anstee QM \& Goldin RD (2006) Mouse models in nonalcoholic fatty liver disease and steatohepatitis research. Int J Exp Path 87, 1-16.

85. Chawla RK, Watson WH, Eastin CE, et al. (1998) S-adenosylmethionine deficiency and TNF- $\alpha$ in lipopolysaccharideinduced hepatic injury. Am J Physiol 275, G125-G129.

86. Griffin ME, Wilson KA, White MR, et al. (1994) Dietary choline requirement of juvenile hybrid striped bass. J Nutr $\mathbf{1 2 4}$, 1685-1689.

87. Slow S \& Garrow TA (2006) Liver choline dehydrogenase and kidney betain-homocysteine methyltrasferase expression are not affected by methionine or choline intake in growing rats. J Nutr 136, 2279-2283. 
88. Tocher DR, Bendiksen EA, Campbell PJ, et al. (2008) The role of phospholipids in nutrition and metabolism of teleost fish. Aquaculture 280, 21-34.

89. Kjær MA, Vegusdal A, Giøen T, et al. (2008) Effect of rapeseed oil and dietary $n-3$ fatty acids on triacylglycerol synthesis and secretion in Atlantic salmon hepatocytes. Biochim Biophys Acta 1781, 112-122.

90. Wang HX, Chen XL \& Fisher EA (1993) n-3 Fatty-acids stimulate intracellular degradation of apoprotein $\mathrm{B}$ in rat hepatocytes. J Clin Invest 91, 1380-1389.

91. Wong SH, Fisher EA \& Marsh JB (1989) Effects of eicosapentaenoic and docosahexaenoic acids on apoprotein-B messenger-RNA and secretion of very low-density lipoprotein in HepG2 cells. Arteriosclerosis 9, 836-841.

92. Sundaram M \& Yao ZM (2010) Recent progress in understanding protein and lipid factors affecting hepatic VLDL assembly and secretion. Nutr Metab 7, 35.
93. Caballero MJ, Izquierdo MS, Kjørsvik E, et al. (2003) Morphological aspects of intestinal cells from gilthead seabream (Sparus aurata) fed diets containing different lipid sources. Aquaculture 225, 325-340.

94. Caballero MJ, Obach A, Rosenlund G, et al. (2002) Impact of different dietary lipid sources on growth, lipid digestibility, tissue fatty acid composition and histology of rainbow trout, Onchorbynchus mykiss. Aquaculture $\mathbf{2 1 4}$, 253-271.

95. Olsen RE, Myklebust R, Kaino T, et al. (1999) Lipid digestibility and ultrastructural changes in the enterocytes of Arctic char (Salvelinus alpinus L.) fed linseed oil and soyabean lecithin. Fish Physiol Biochem 21, 35-44.

96. Cheal KL, Abbasi F, Lamendola C, et al. (2004) Relationship to insulin resistance of the adult treatment panel III diagnostic criteria for identification of the metabolic syndrome. Diabetes 53, 1195-1200. 